Review

\title{
Nanochitosan: Commemorating the Metamorphosis of an ExoSkeletal Waste to a Versatile Nutraceutical
}

\author{
Iyyakkannu Sivanesan ${ }^{1}{ }^{(}$, Manikandan Muthu ${ }^{2}$, Judy Gopal ${ }^{2}{ }^{-}$, Nazim Hasan ${ }^{3}$, Syed Kashif Ali ${ }^{3}$, \\ Juhyun Shin ${ }^{4}$ (D) and Jae-Wook $\mathrm{Oh}^{4, *}$
}

1 Department of Bioresources and Food Science, Konkuk University, 120 Neungdong-ro, Gwangjin-gu, Seoul 05029, Korea; isivanesan@gmail.com

2 Laboratory of Neo Natural Farming, Chunnampet, Tamil Nadu 603 401, India; bhagatmani@gmail.com (M.M.); jejudy777@gmail.com (J.G.)

3 Department of Chemistry, Faculty of Science, Jazan University, Jazan P.O. Box 114, Saudi Arabia; hhasan@jazanu.edu.sa (N.H.); skali_169@yahoo.com (S.K.A.)

4 Department of Stem Cell and Regenerative Biotechnology, Konkuk University, Seoul 05029, Korea; junejhs@konkuk.ac.kr

* Correspondence: ohjw@konkuk.ac.kr; Tel.: +82-2-2049-6271; Fax: +82-2-455-1044

Citation: Sivanesan, I.; Muthu, M.; Gopal, J.; Hasan, N.; Kashif Ali, S.; Shin, J.; Oh, J.-W. Nanochitosan:

Commemorating the Metamorphosis of an ExoSkeletal Waste to a Versatile Nutraceutical. Nanomaterials 2021, 11 , 821. https://doi.org/10.3390/ nano11030821

Academic Editor: Takuya Kitaoka

Received: 18 February 2021

Accepted: 17 March 2021

Published: 23 March 2021

Publisher's Note: MDPI stays neutral with regard to jurisdictional claims in published maps and institutional affiliations.

\begin{abstract}
Chitin (poly- $N$-acetyl-D-glucosamine) is the second (after cellulose) most abundant organic polymer. In its deacetylated form—chitosan-becomes a very interesting material for medical use. The chitosan nano-structures whose preparation is described in this article shows unique biomedical value. The preparation of nanochitosan, as well as the most vital biomedical applications (antitumor, drug delivery and other medical uses), have been discussed in this review. The challenges confronting the progress of nanochitosan from benchtop to bedside clinical settings have been evaluated. The need for inclusion of nano aspects into chitosan research, with improvisation from nanotechnological inputs has been prescribed for breaking down the limitations. Future perspectives of nanochitosan and the challenges facing nanochitosan applications and the areas needing research focus have been highlighted.
\end{abstract}

Keywords: chitin; chitosan; nanochitosan; drug delivery; biomedical applications; nutraceutical

\section{Introduction}

Henri Braconnot, in 1811, discovered chitin in mushrooms. Rouget in 1859, heated chitin in an alkaline medium to get an organic acid-soluble material [1] and Hoppe Seyler (1894) named this acid-soluble material as chitosan. In 1950 the structure of chitosan was elucidated. Crini [2] has extensively reviewed the 220 years of chitin history. Chitosan (CS) is obtained from chitin. Chitin is naturally extracted from yeast, fungi, algae, silkworms, cockroaches, honey bees and marine aquatic animals such as arthropods, crustaceans, cephalopods, lobsters, mollusks and shrimps [3]. $\alpha$-Chitin in the 3D form is also reported to be found in sponges [4]. CS is obtained from the deacetylation of chitin. It is a linear and cationic biodegradable carbohydrate polymer. It is non-toxic and renewable [5]. CS and chitin are differentiated on the basis of the $\mathrm{N}$-acetylamine group. Chitin has an amino group at the C2 position, whereas chitosan is a product of alkaline or enzymatic deacetylation of chitin. The degree of deacetylation (DD) of chitin ranges from $60 \%$ to $100 \%$ [6]. It consists of randomly distributed $\beta$-(1-4)-linked $N$-acetyl-D-glucosamine (GlcNAc) and D-glucosamine $(\mathrm{GlcN})$. It is the occurrence of the amino group at the $\mathrm{C} 2$ position, that result in the superior properties of chitosan [6-8]. These superior properties of CS include anticoagulant properties, fluidity, water solubility and high water reducing ratio $[9,10]$ and biological properties such as controlled drug delivery, gelation, enhancement of permeation, mucoadhesion, targeting the colon and efflux pump inhibition [11-13]. CS is a high-value biomacromolecule, owing to its use in biomedical applications. Biocompatibility and low toxicity, immunity, and biodegradability are the key traits that have made CS biomedically 
significant. The antimicrobial property of chitosan has been reported to be high at low $\mathrm{pH}$ because of the cationic amino group [14]. The adhesive nature of chitosan enables its tissue adherence, extending its leverage in dentistry, orthopaedics, wound healing and ophthalmology [15-17]. CS also possesses a high affinity for negatively charged cell membranes, thus showing enhanced site-specific targeting abilities [18].

Inspite of the unique properties of CS, its clinical applications are limited by its poor mechanical properties $[19,20]$. Mechanical properties such as, modulus of elasticity, tensile strength, elongation, hardness and fatigue limit, which are essentials for any biomaterial, are those that at a deficit in CS. Hence, to overcome these limitations, CS has been subjected to a number of modifications [21,22]. Free amino and hydroxyl groups have generated various other CS derivatives $[23,24]$, that have been applied for biomedical and pharmaceutical processes, such as tissue engineering, drug delivery, gene delivery, vaccine delivery, wound healing and cosmetics [25-27].

What makes chitosan attractive, is the fact that it is derived from chitin and that chitin is obtained from the exoskeleton of various classes of organisms mentioned above. With the source material being shrimp, squid, lobster, crab shell wastes, this valuable asset is an added asset. This makes this material a cost-effective and renewable resource extracted from crustacean waste generated from the seafood industry. The general process of isolation of chitin from natural sources is through demineralization and deproteinization of the waste material with strong acids and bases, such as $\mathrm{HCl}$ and $\mathrm{NaOH}$ [28]. Through enzymatic or chemical deacetylation, chitin can be converted to its most well-known derivative, CS. The various methods involved in the isolation of chitin and recovery of chitosan from chitin have been well researched and reviewed [29-31]. Figure 1 gives the overall scheme of the journey from shell wastes to nanochitosan.

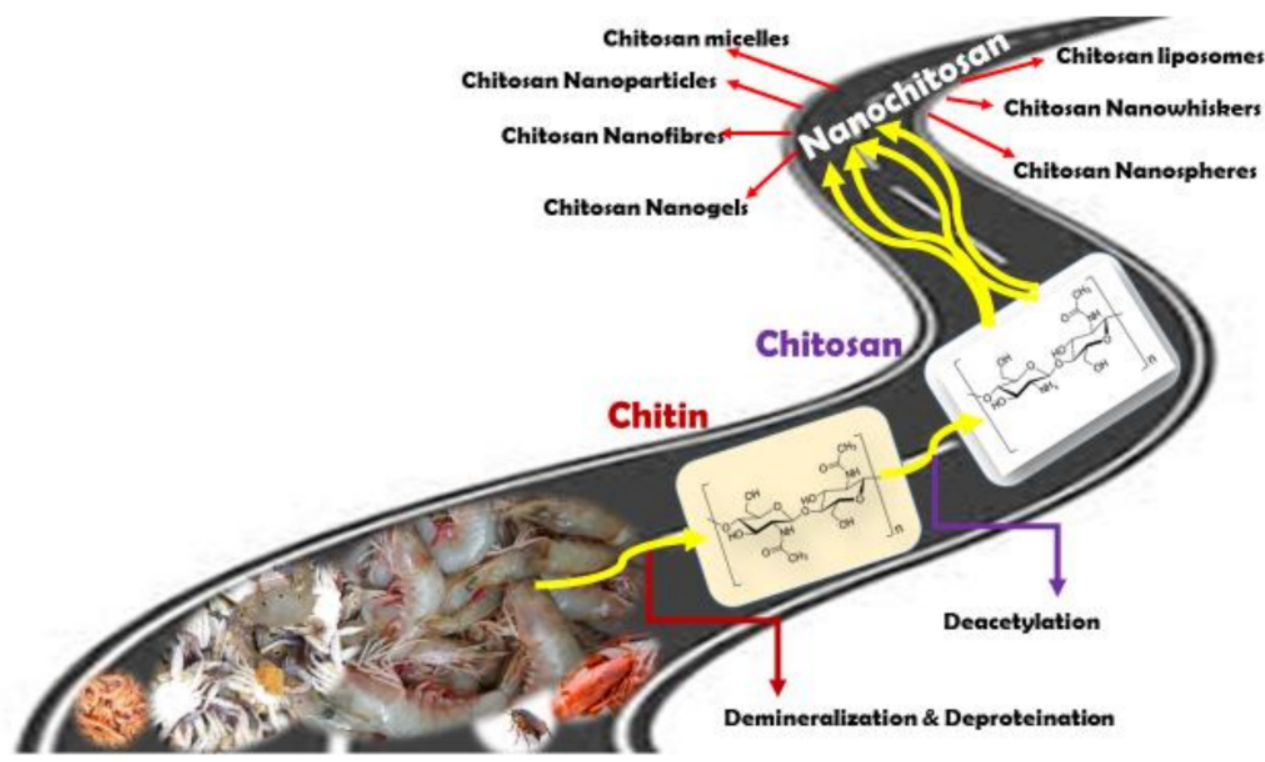

Figure 1. Tracing the journey from shell waste to nanochitosan.

In this current review, the preparation of nano chitosan-based materials from chitin and chitosan has been briefly presented. The unique enhanced biomedical applications through nano-aturization of chitosan have been summarized and the future perspectives presented.

\section{Preparation of Nanochitosan}

Over the last few decades, novel nanomaterials have been successfully developed from CS and widely applied for targeted drug delivery. CS is well-known for drug delivery based on the following features: (1) biocompatibility, (2) defending drug molecules from gastric acids and blood flow responses, (3 adherence to mucosal tissues to improve drug absorp- 
tion, (4) binding with anionic DNA by electrostatic action and (5) targeted colon administration [32-34]. Reviews on chitosan-based nanoparticle systems for disease treatment have been published reporting the biological applications of CS [35,36]. Moreover, since the CS backbone has multiple free amino and hydroxyl groups, these have been used for the construction of CS-based nanomaterials, such as nanogels, nanoparticles (NPs), micelles, liposomes, nanofibers, and nanospheres. These CS-based nanomaterials have been used for various biomedical applications [37-39]. Materials reported to be used during the preparation of CS nanoparticles/CS composites include, polymers such as dextran sulfate [40], sodium alginate [41,42], carrageenan [43], arabic gum [44], glucomannan [45], carboxymethyl cellulose [46], chondroitin sulfate [47], pectin [48], heparin [49], hyaluronic acid [50], sodium lauryl sulfate [51], cyclodextrins [52], poly- $\gamma$-glutamic acid [53,54] and poly(acrylic acid) [55], insulin [56] and occasionally DNA [57,58]. Examples of such composites are chitosan/alginate/tripolyphosphate [59], chitosan/glucomannan/tripolyphosphate [60], chitosan/hyaluronic acid/tripolyphosphate [50] or chitosan/cyclodextrin/tripolyphosphate [52] nanoparticles.

\section{Methods of Nanochitosan Preparations}

Ever since the first report in 1994 by Ohya et al. [61], diverse techniques have been optimized for the preparation of CSNPs. Methods such as emulsification and varied kinds of coacervation and their respective modifications. Emulsion-droplet coalescence [62], emulsion solvent diffusion [63], reverse micellar method [64], ionic gelation, polyelectrolyte complexation $[41,65]$ and desolvation $[66]$ are some of the prevalent methodologies that are in practice. These generally are prototypes of bottom-up fabrication processes, comprising of assembly of molecules to yield defined nanostructures [67] which display size polydispersity [68]. It is assumed that larger nanoparticles possess higher drug loading capacity, while smaller nanoparticles have the advantage of being able to easily assess tissues or cells. Hence, given this fact either sizes stand their own advantage.

Ionic gelation involves, dissolving CS in an aqueous acidic solution to obtain cationic chitosan [69]. This solution is added to anionic tripolyphosphates (TPP) solution to yield spherical particles [70,71]. In an emulsion cross-linking method, the aqueous CS solution is emulsified in the oil phase and the aqueous droplets are stabilized using a suitable surfactant,. Then, glutaraldehyde (cross-linking agent) is added to precipitate nanoparticles $[61,72,73]$. Spray-drying is another method where, CSNPs are prepared by use of a nano-spray dryer [74-77]. Emulsion droplet coalescence is widely reported for drug delivery applications, a stable emulsion containing an aqueous solution of CS with the drug is introduced into liquid paraffin oil. $\mathrm{CS}$ aqueous solution in $\mathrm{NaOH}$ in liquid paraffin oil is another emulsion system, these different emulsions are mixed under high-speed stirring, to precipitate CS droplets to obtain small size particles $[78,79]$. The same group applied the above technology to prepare gadolinium-loaded chitosan nanoparticles, for neutron-capture therapy of cancer [78].

The emulsion solvent diffusion method is an adaptation of the procedure that produces PLGA-based nanoparticles [80]. This involves the addition of an organic phase to an aqueous solution containing CS and a stabilizer [63]. Nanoprecipitation is another technique, where CS is dissolved in a suitable solvent to form the diffusing phase, which is added to the dispersing phase with small amounts of polysorbate- 80 to yield smaller NPs [81]. Reverse micellisation, [82,83], uses a lipophilic surfactant (sodium bis (ethyl hexyl) sulfosuccinate or acetyl trimethyl ammonium bromide) dissolved in n-hexane. CS solution, drug and glutaraldehyde are added to the organic phase under continuous stirring to obtain nanoparticles $[64,84,85]$. Desolvation/simple coacervation/phase separation, is another process reported for obtaining nanochitosan particles [86-88]. Modified ionic gelation uses aqueous acrylic acid monomer solution in aqueous CS solution for ionic gelation $[55,89,90]$. Emulsion solvent diffusion [63], ionic gelation and polyelectrolyte complexation methods [91,92] have also been reported. Grenha, 2012 [93] have elabo- 
rated extensively on the preparation techniques and the ensuing chitosan nanoparticle applications in their excellent review.

\section{Biomedical Milestones of Nanochitosan}

Nanomedicine has led to ennumerable breakthroughs in the detection, diagnosis, and treatment of various diseases [94]. Nanochitosan have been proven as drug carriers, for controlled drug release. Chitosan has been able to improve drug solubility and stability, enhance efficacy and reduce toxicity.

\subsection{Antitumor Applications of Nanochitosan}

The antitumor effects of chitosan, confirm their prospective application as antitumor drug and as a drug carrier [95]. Due to unique features such as compatibility and biodegradability, nanochitosan have emerged as a vital tool for drug delivery applications specifically for cancer [96]. Nanochitosan have been deployed for the delivery of anti-cancer drugs like methotrexate [97], epirubicin [98], curcumin [99,100], 5-flourouracil [101,102], cysplatin [103], mitomycin C [104], paclitaxel [105], and tamoxifen [106], docetaxel [107], doxorubicin (DOX) $[64,91]$. Nanochitosan has been successful in focusing the anti-tumor efficacy, control release and by drug targeting towards tumor (reducing widespread toxicity). Nanochitosan have been successful in, releasing $50 \%$ of methotrexate loaded in $48 \mathrm{~h}$ [97], releasing the drug cysplatin slowly [103], loading epirubicin into cholesterolmodified CS, followed by their $\mathrm{pH}$-dependent release in vitro [98], encapsulation and release of doxorubicin in CS-based NPs [91], encapsulation of mitomycin C (chemotherapeutic) for bladder cancer cells therapy [104], reducing drug toxicity and tumor volume in mice [107], carrier/vehicle/prodrug of cancer therapy [100,105,108-110], encapsulation of dextran-doxorubicin conjugate in CSNPs [64], a controlled release increase tamoxifen chemotherapeutic efficiency [106] and chemotherapy of breast cancer to reduce traditional chemo-related side-effects [102].

\subsection{Drug Delivery Applications of Nanochitosan}

Nano mucosal delivery carriers are useful for mucosal drug delivery because they are prone to obstruction and have need protection [111]. Due to its mucoadhesive property, nanochitosan has been extensively used for this purpose [112-114]. De Campos et al. have shown that CS nanoparticles remained attached to the rabbits' cornea and conjunctiva for up to $24 \mathrm{~h}$ [115]. Other studies have confirmed the use of mucoadhesive chitosan (CS)-sodium Alg nanoparticles for prolonged topical ophthalmic delivery of the antibiotic, gatifloxacin [116,117]. Sarah Baltzley et al. have reported the use of nanochitosan particles for intranasal delivery in order to amplify olanzapine systemic bioavailability [118]. Abeer M. Al-Ghananeem et al. reported nanoCS for intranasal delivery for didanosine systemic and brain targeting [119]. Park et al. demonstrated targeted delivery to the liver using galactosylated-chitosan-graft-dextran DNA complexes [120]. Similarly, transferrin-chitosan-DNA nanoparticles have been employed for targeted drug delivery [93]. Nanochitosan have been reported for mucosal delivery of antigen vaccines [121-132]. Nanochitosan are suggested to be ideally useful for modern vaccinology, facilitating oral and nasal delivery of nanoparticles with protective immune responses. The nanosize dimensions of nanochitosan aids in their effective uptake by M cells, in mucosa, gut, nasal and bronchus-associated lymphoid tissues [122].

Nanochitosan have been widely reported for drug delivery with respect to infectious diseases. The functional groups aid in guiding the loaded drugs to the infection site. Sustained biodegradation of chitosan helps in the controlled and slow release of loaded moieties and is competent in reducing dosing frequency [133-135]. CS nanoparticles have been reported in delivery of anti-microbial drugs such as: cefazolin [136], rifampicin [137-139], isoniazid [138,140] and tetracycline [141], amphotericin B [142-144],vancomycin [145,146], daptomycin [147], ofloxacin [148], ciprofloxacin [140], amoxicillin [149]. Nanochitosan have been confirmed to exhibit better encapsulation efficiency (EE), good stability against 
Klebselia pneumonia, P. aeruginosa and lactamase positive E. coli [136]. Other properties of nanochitosan towards antimicrobicidal effects include, rapid bactericidal activity and reduced dose frequency [137], high entrapment efficiency, sustained release, prolong residence time [143], inhibition of H. pylori [149]. Bivas-Benita et al. [150] demonstrated the pulmonary delivery of DNA vaccines against tuberculosis.

CS is also recognized for oral drug delivery [151]. Nanochitosan has been successfully used against ulcerative colitis, Crohn's disease, pseudomembranous colitis and irritable bowel syndrome [152,153]. CS is recognized as the most predominant polymer with respect to colon targeted delivery. This is owing to the fact that it dissolves in acidic $\mathrm{pH}$ of the stomach and swells up at intestinal $\mathrm{pH}$ ranges [154]. Nanochitosan have been reported to improve uptake of HT-29 cell and colorectal cancer [155]. The release of 5-aminosalicylic acid from nanochitosan based on ion-exchange mechanism is reported [156]. S-DNA chitosan nanoparticles were more stable in the upper regions of the small intestine [157] and have been reported for targeting drugs to colon tumor [158] and have been also reported for endoscopic detection of colorectal cancer [159] and apoptosis initiation by transretinoic acid bearing methoxy poly(ethylene glycol)-grafted nanochitosan [160]. Moreover, hyaluronic acid coupled CSNPs were 60-fold more effective on HT-29 cells [161].

Nanochitosan have been extensively used for ocular drug delivery. Drug delivery of CyA [115,162], FITC-BSA [163,164], indomethacin [165,166], pilocarpine [167,168], pDNA [169], and prednisolone [170] has been successfully accomplished. The transdermal route is usually a more "patient-friendly" approach overcoming stomach-based side effect [171]. Raida Al-Kassas et al. used nanochitosan particles dispersed in mucoadhesive gel for transdermal delivery [172]. In another study, Anita Hafner et al. investigated the application of nanochitosan particles for transdermal melatonin [173].

CSNPs have been applied for anti-inflammatory drug delivery of drugs such as zaltoprofen [174], hydrocortisone [175], ketorolac tromethamine [176], tretinoin [177]. The use of nanochitosan particles has reported increasing anti-inflammatory activity and efficacy as well as physical stability. CSNPs have also been used for anti-HIV drugs such as, lamivudine [178], zidovudine [179]; anti-malarial drugs such as chloroquine [180], antitubercular drugs including rifampicin and isoniazid [138]; muscle relaxants like thiocolchicoside [181] and oral hypoglycemic medications such as insulin [182].

\subsection{Miscellaneous Applications of Nanochitosan}

CS-based DNA flu vaccine for intranasal administration has also been formulated and demonstrated $[132,133]$. Smitha et al. reported amidase encapsulated O carboxymethyl CSNPs against $S$. aureus infections. Nanochitosan has been established as the most suitable candidate for the oral vaccine delivery system [134]. Pattani et al. [135] studied the immunological and membrane effects of nanochitosan in the wound-healing process. CS-TPP nanoparticles have demonstrated a higher potential for safe and cost-effective delivery of siRNA $[183,184]$. Nanochitosan particles have been reported as non-viral vectors for gene delivery and carriers for protein molecules [185-187].

$\mathrm{CS}$ is of high value when it comes to tissue engineering. Being a natural polymer, CS displays excellent biocompatibility [188]. With respect to insulin delivery, CS-dextran sulphate and chitosan Alg nanoparticles have been used as insulin and alternate polypeptides' carriers [41]. Nanochitosan particles have been reported to enhance the systemic absorption of insulin upon nasal instillation [189]. Insulin-loaded nanochitosan particles have been effective in reducing glucose levels in a diabetic rat model [53]. Figure 2 gives a bird's eye overview of Sections 2 and 3. 


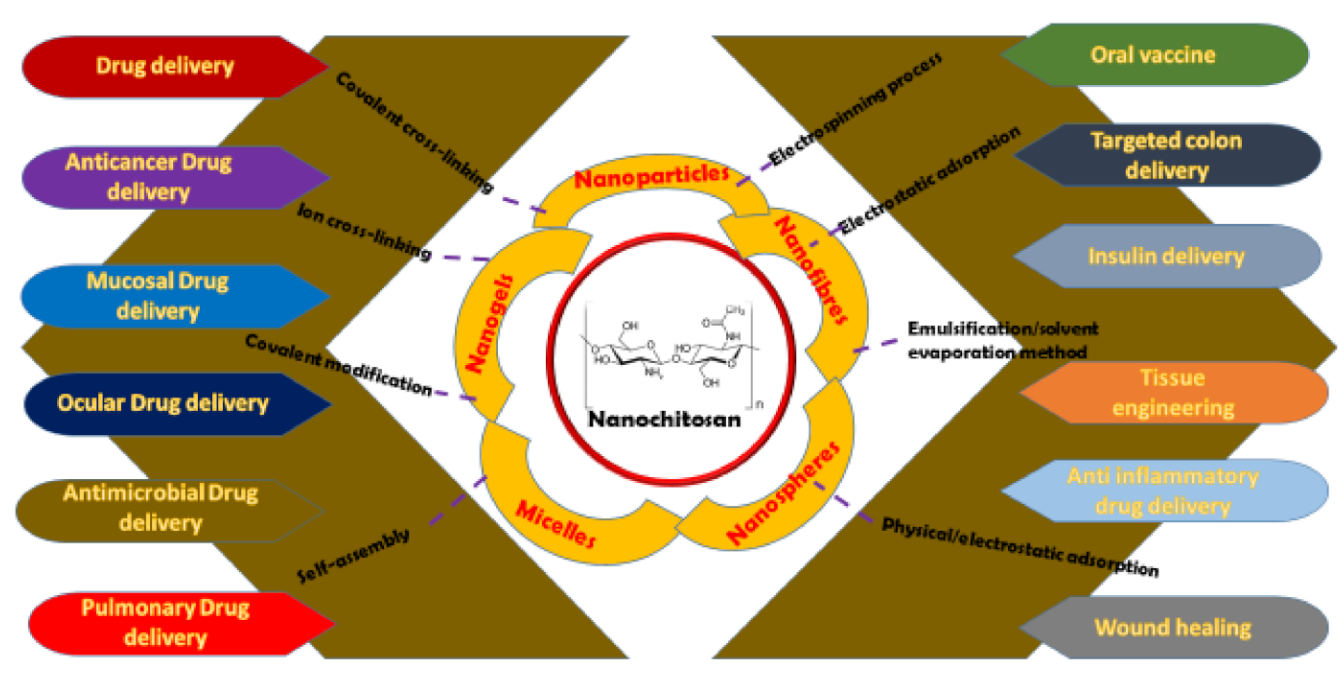

Figure 2. Overview of nanochitosan preparation techniques and applications.

\section{Challenges Facing Nanochitosan Applications and Future Perspectives}

CS by itself is a valuable asset, given the fact that it is recovered from exoskeletal wastes. CS recovery has brought meaningful utility to the tons of marine shell waste being dumped into the environment. Through this retrieval, dual purposes are solved through the proper usage of marine wastes for generating a versatile product. Nanochitosan has further stretched the limits of utility of this versatile product in leaps and bounds. As in every case, nano has certainly pushed the limits of bulk materials way beyond human perception, in case of CS too, as expected outcomes have been realized. As summarized in the earlier sections, nanochitosan has come a long way and nanomedicine has greatly benefitted from its inputs.

\subsection{Clinical Challenges of Nanochitosan}

Discussing the challenges facing nanochitosan biomedical applications, it needs to be highlighted that the clinical administration of CS-based drug vectors still faces a limitation owing to their undisclosed risks. A nasal formulation of morphine (RylomineTM) based on CS is currently in Phase 2 clinical trials (UK and EU) and Phase 3 clinical trial. It is predicted that when it lands on the market it will encounter comparison with similar products and may be answerable for the unforeseen impacts on humans [190]. CS by itself has very few reports for their clinical studies or trials, nanochitosan based work is even more scarce. This apparently indicates that there is a gap between theory and practice, hence this needs to be worked on. Whatever may be the credentials of a nanomaterial for biomedical applications, if it does not progress from benchtop to bedsides, no progress is real progress.

Moreover, in vivo studies involving nanochitosan are also merely a handful, in vivo studies are the preludes to clinical trials, these need to be initiated and the reasons why these haven't been initiated need to be assessed and addressed.

\subsection{Limiting Challenges in Nanomodifications of Chitosan}

Few nanomodifications of chitosan have been reported (with nanochitosan particles being the most predominant), when there are numerous nano morphologies and unique properties specific to each of these morphologies, varied synthesis methods need to be worked on and tested for their biomedical applications. A distinct list as to the limitation of nanochitosan with respect to biomedical applications is yet to emerge. Only when we know the disclosure of the limitations we have hit on, will there be possibilities to probe overcoming those.

Composites in materials science, have enabled considerable advances and breakthroughs, since properties of two or three different materials combine and their strengths 
integrate and their weaknesses overcome. This review has presented the handful of chitosan composites reported thus far, Table 1 gives the consolidated list of the chitosan related composites and their inputs in biomedical applications [190-227]. As observed from the table, there are not many chitosan composites, the diversity of the composites are also limited, most of the composites involve chitosan and other polymers and acid moieties. The introduction of composites has been essentially useful in extending the application of CS to rather demanding biomedical aspects such as, wound dressing, antimicrobial, skin tissue engineering, bone grafting, wound healing and the like. Nanochitosan composites involving metal nanomaterials is the least (carboxymethyl chitosan-PVA/Ag nanoparticles and gold nanocluster-conjugated chitosan) represented, also composites mostly involve chitosan associations with other polymers, while nanochitosan based composites are meagerly represented. Few studies involving chitosan nanofiber and nanoparticle based composites are those that are available, there is definitely a lot more to explore and improvisations to be made through the integration of materials.

Table 1. Examples of nanochitosan composites applied in biomedical applications.

\begin{tabular}{|c|c|c|c|}
\hline Nanochitosan composites & Biomedical Application & Associated Drug & Reference \\
\hline Chitosan + alginate + Pluronic & Drug delivery & Curcumin & [191] \\
\hline $\operatorname{Poly}(\beta$-malic acid $)-\gamma$-chitosan-Linoleic acid & Drug delivery & Paclitaxel & [192] \\
\hline $\begin{array}{l}\text { Poly(ethylene-glycol)- } \gamma \text { carboxymethyl } \\
\text { chitosan }\end{array}$ & Drug delivery & Dox & [193] \\
\hline $\begin{array}{c}\text { Chitosan/poly(ethylene glycol)- } \\
\text { glycyrrhetinic acid }\end{array}$ & Drug delivery & Dox & [194] \\
\hline Chitosan-Cholanic acid & Drug delivery & Paclitaxel & [195] \\
\hline Chitosan Glyceryl monooleate & Drug delivery & Paclitaxel & [196] \\
\hline Chitosan Cholesterol & Drug delivery & Epirubicin & [98] \\
\hline $\begin{array}{l}\text { Carboxymethyl } \\
\text { Chitosan-PVA }\end{array}$ & wound dressings & NA & [197] \\
\hline $\begin{array}{c}\text { Carboxymethyl } \\
\text { Chitosan-PVA/silk fibroin }\end{array}$ & wound dressings & NA & [198] \\
\hline Carboxymethyl Chitosan-PEO & Antimicrobial & NA & [199] \\
\hline Chitosan/PEO nanofibers & wound dressings & NA & [200] \\
\hline $\begin{array}{l}\text { Carboxymethyl Chitosan-PVA/Ag } \\
\text { nanoparticles }\end{array}$ & antibacterial & NA & [201] \\
\hline Quaternized chitosan-coPLA & antitumor & DOX & [202] \\
\hline Quaternized chitosan-PVA & Antibacterial & NA & {$[203,204]$} \\
\hline Quaternized chitosan-PVP & Antibacterial & NA & [205] \\
\hline Quaternized chitosan-PLA & $\begin{array}{c}\text { Antitumor } \\
\text { Wound dressing }\end{array}$ & NA & {$[206,207]$} \\
\hline Quaternized chitosan-Graphene & Virus removal & NA & {$[208]$} \\
\hline Quaternized chitosan-Organic rectorite & Antibacterial & NA & [209] \\
\hline PEG-graft chitosan & Drug release & PLGA & [210] \\
\hline 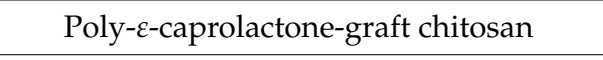 & Skin tissue engineering & & [211] \\
\hline Iminochitosan & Wound healing & NA & [212] \\
\hline Cyanoethyl chitosan & Wound dressing & NA & [213] \\
\hline N-Methylene phosphonic chitosan & Bone grafting & NA & [214] \\
\hline
\end{tabular}


Table 1. Cont.

\begin{tabular}{|c|c|c|c|}
\hline Nanochitosan composites & Biomedical Application & Associated Drug & Reference \\
\hline Hydroxypropyl Chitosan-Organic rectorite & Antibacterial & NA & [215] \\
\hline Hydroxyapatite-chitosan nanocomposite & Colon cancer theraphy & Celecoxib & [216] \\
\hline PGLA-chitosan & Rat glioblastoma & $\begin{array}{c}\text { Carmustine (BCNU), } \\
\mathrm{O}(6) \text {-benzylguanine }(\mathrm{BG})- \\
\text { therapeutic agents }\end{array}$ & [217] \\
\hline Hyaluronic acid (HA)-CS nanoparticles & Breast cancer & $\begin{array}{l}\text { miR-34a and doxorubicin } \\
\text { (DOX) }\end{array}$ & [218] \\
\hline Chitosan based glycolipid-like & Human ovarian cancer cells & Paclitaxel (PTX) & [219] \\
\hline Albumin-chitosan & Mesothelioma therapy & Onconase (ONC) & [220] \\
\hline Chitosan coated mixed micelles & $\begin{array}{l}\text { Multidrug resistant cancer } \\
\text { cells }\end{array}$ & siRNA and Doxorubicin & [221] \\
\hline $\begin{array}{l}\text { Stearic acid-grafted chitosan } \\
\text { oligosaccharide (CSO-SA) }\end{array}$ & Cancer therapy & $\begin{array}{l}\text { Polymer-drug conjugate } \\
\text { of doxorubicin }\end{array}$ & [222] \\
\hline $\begin{array}{l}\text { Deoxycholic acid-O carboxymethyl } \\
\text { chitosan }\end{array}$ & Liver cancer & $\begin{array}{l}\text { Ginsenoside compound } \mathrm{K} \\
(\mathrm{CK})\end{array}$ & [223] \\
\hline Cholesterol conjugated chitosan & Human lung carcinoma cells & Curcumin & [224] \\
\hline $\begin{array}{l}\text { Fluorescent gold nanocluster-conjugated } \\
\text { chitosan }\end{array}$ & Lung cancer & Methotrexate & [225] \\
\hline Glycol chitosan nanopolymers (psi-TGC) & $\begin{array}{l}\text { knockdown of tumour Protein } \\
\text { for cancer gene therapy }\end{array}$ & Poly siRNA & [226] \\
\hline Glycol chitosan & $\begin{array}{l}\text { In vivo inhibition of tumour } \\
\text { via Gene therapy }\end{array}$ & Poly siRNA & [226] \\
\hline $\begin{array}{c}\text { Chitosan: poly(lactic-co-glycolic acid) } \\
\text { nanoparticles }\end{array}$ & $\begin{array}{c}\text { Silencing of aquaporin-1 } \\
\text { cancer cells via Gene therapy }\end{array}$ & siRNA & [227] \\
\hline $\begin{array}{c}\mathrm{N} \text {-sulfonato-N,O-carboxymethylchitosan } \\
\text { (NOCCS) }\end{array}$ & $\begin{array}{l}\text { In vivo cancer cells via } \\
\text { Photodynamic therapy }\end{array}$ & mTHPP. & [228] \\
\hline
\end{tabular}

Abbreviations: PEO, poly(ethylene oxide); PVA, poly(vinyl alcohol); PEG, poly(ethylene glycol); PLGA, poly(D,L-lactide-co-glycolide); PLA, poly(L-lactide); LA, L-lactide; coPLA, poly(L-lactide-co-D,L-lactide); PVP, polyvinylpyrrolidone; PCL, poly-e-caprolactone.

\subsection{Limitations in Biomedical Applications of Nanochitosan}

As much as drug delivery of nanochitosan has been worked on, not much has been done with respect to other biomedical applications. Biomedical aspects such as, tissue engineering, wound healing, antimicrobial (especially antiviral) activity, are all areas craving attention. Much of the research focus of nanochitosan has been targeted in and around drug delivery applications, leading to narrowing down the scope of biomedical applications of nanochitosan to this area alone. This review found reasonable lack of reports in this direction, which we highlight as concerns that could eventually become directions for future perspectives.

\section{Conclusions}

The credentials of shell waste-derived nanochitosan have been reviewed and the lacunae in taking this cost-effective and renewable resource towards clinical applications are speculated and discussed. The preparation of nanochitosan and the biomedical applications of nanochitosan have been reviewed. The limitations and challenges facing the expansion and deployment of nanochitosan to clinical settings has been addressed. The very reason that nanochitosan has been retrieved from exoskeletal wastes, makes it a valuable asset and this review emphasizes that there is more future and promises to lie ahead inspite of the challenges. 
Author Contributions: Conceptualization, writing-original draft preparation, I.S., M.M., J.G.; supervision, writing—review and editing, project administration, N.H., S.K.A., J.S., J.-W.O. All authors have read and agreed to the published version of the manuscript.

Funding: This research received no external funding.

Acknowledgments: This work was supported by the KU Research Professor Program of Konkuk University.

Conflicts of Interest: The authors declare no conflict of interest.

\section{References}

1. Felt, O.; Buri, P.; Gurny, R. Chitosan: A unique polysaccharide for drug delivery. Drug Dev. Ind. Pharm. 1998, 24, 979-993. [CrossRef] [PubMed]

2. Crini, G. Historical review on chitin and chitosan biopolymers. Environ. Chem. Lett. 2019, 17, 1623-1643. [CrossRef]

3. Kim, S.-K. Chitin, Chitosan, Oligosaccharides and Their Derivatives: Biological Activities and Applications, 1st ed.; CRC Press: Boca Raton, FL, USA, 2010.

4. Wysokowski, M.; Bazhenov, V.V.; Tsurkan, M.V.; Galli, R.; Stelling, A.L.; Stocker, H.; Kaiser, S.; Niederschlag, E.; Gartner, G.; Behm, T.; et al. Isolation and identification of chitin in three-dimensional skeleton of Aplysina fistularis marine sponge. Int. J. Biol. Macromol. 2013, 62, 94-100. [CrossRef]

5. De Oliveira, A.C.; Vilsinski, B.H.; Bonafe, E.G.; Monteiro, J.P.; Kipper, M.J.; Martins, A.F. Chitosan content modulates durability and structural homogeneity of chitosan-gellan gum assemblies. Int. J. Biol. Macromol. 2019, 128, 114-123. [CrossRef] [PubMed]

6. Dutta, P.K.; Dutta, J.; Tripathi, V.S. Chitin and chitosan: Chemistry, properties and applications. J. Sci. Ind. Res. 2004, 63, 20-31.

7. Kurita, K. Chemistry and application of chitin and chitosan. Polym. Degrad. Stabil. 1998, 59, 117-120. [CrossRef]

8. Hudson, S.M.; Smith, C. Polysaccharides: Chitin and chitosan: Chemistry and technology of their use as structural materials. In Biopolymers from renewable resources; Kaplan, D.L., Ed.; Springer: Berlin/Heidelberg, Germany, 1998; pp. 96-118. [CrossRef]

9. Jayakumar, R.; Nwe, N.; Tokura, S.; Tamura, H. Sulfated chitin and chitosan as novel biomaterials. Int. J. Biol. Macromol. 2007, 40, 175-181. [CrossRef] [PubMed]

10. Lv, S.H.; Liu, J.J.; Zhou, Q.F.; Huang, L.; Sun, T. Synthesis of Modified Chitosan Superplasticizer by Amidation and Sulfonation and Its Application Performance and Working Mechanism. Ind. Eng. Chem. Res. 2014, 53, 3908-3916. [CrossRef]

11. Bravo-Osuna, I.; Vauthier, C.; Farabollini, A.; Palmieri, G.F.; Ponchel, G. Mucoadhesion mechanism of chitosan and thiolated chitosan-poly(isobutyl cyanoacrylate) core-shell nanoparticles. Biomaterials 2007, 28, 2233-2243. [CrossRef]

12. Dunnhaupt, S.; Barthelmes, J.; Rahmat, D.; Leithner, K.; Thurner, C.C.; Friedl, H.; Bernkop-Schnurch, A. S-Protected Thiolated Chitosan for Oral Delivery of Hydrophilic Macromolecules: Evaluation of Permeation Enhancing and Efflux Pump Inhibitory Properties. Mol. Pharm. 2012, 9, 1331-1341. [CrossRef]

13. Hejjaji, E.M.A.; Smith, A.M.; Morris, G.A. Evaluation of the mucoadhesive properties of chitosan nanoparticles prepared using different chitosan to tripolyphosphate (CS:TPP) ratios. Int. J. Biol. Macromol. 2018, 120, 1610-1617. [CrossRef]

14. Goy, R.C.; De Britto, D.; Assis, O.B.G. A Review of the Antimicrobial Activity of Chitosan. Polimeros 2009, 19, 241-247. [CrossRef]

15. Needleman, I.G.; Smales, F.C.; Martin, G.P. An investigation of bioadhesion for periodontal and oral mucosal drug delivery. J. Clin. Periodontol. 1997, 24, 394-400. [CrossRef] [PubMed]

16. Felt, O.; Furrer, P.; Mayer, J.M.; Plazonnet, B.; Buri, P.; Gurny, R. Topical use of chitosan in ophthalmology: Tolerance assessment and evaluation of precorneal retention. Int. J. Pharmaceut. 1999, 180, 185-193. [CrossRef]

17. Magetsari Ph, D.R.; Dewo Ph, D.P.; Saputro Md, B.K.; Lanodiyu Md, Z. Cinnamon Oil and Chitosan Coating on Orthopaedic Implant Surface for Prevention of Staphylococcus Epidermidis Biofilm Formation. Malays. Orthop. J. 2014, 8, 11-14. [CrossRef]

18. Fu, S.; Xia, J.; Wu, J. Functional Chitosan Nanoparticles in Cancer Treatment. J. Biomed. Nanotechnol. 2016, 12, 1585-1603. [CrossRef] [PubMed]

19. Wang, Y.; Li, B.; Xu, F.; Han, Z.; Wei, D.; Jia, D.; Zhou, Y. Tough Magnetic Chitosan Hydrogel Nanocomposites for Remotely Stimulated Drug Release. Biomacromolecules 2018, 19, 3351-3360. [CrossRef]

20. Liu, D.; Li, J.; Pan, H.; He, F.; Liu, Z.; Wu, Q.; Bai, C.; Yu, S.; Yang, X. Potential advantages of a novel chitosan-N-acetylcysteine surface modified nanostructured lipid carrier on the performance of ophthalmic delivery of curcumin. Sci. Rep. 2016, 6, 28796. [CrossRef]

21. Zhao, X.; Zhou, L.; Li, Q.; Zou, Q.; Du, C. Biomimetic mineralization of carboxymethyl chitosan nanofibers with improved osteogenic activity in vitro and in vivo. Carbohydr. Polym. 2018, 195, 225-234. [CrossRef]

22. Yan, L.; Crayton, S.H.; Thawani, J.P.; Amirshaghaghi, A.; Tsourkas, A.; Cheng, Z. A pH-Responsive Drug-Delivery Platform Based on Glycol Chitosan-Coated Liposomes. Small 2015, 11, 4870-4874. [CrossRef] [PubMed]

23. Ho, D.K.; Frisch, S.; Biehl, A.; Terriac, E.; De Rossi, C.; Schwarzkopf, K.; Lautenschlager, F.; Loretz, B.; Murgia, X.; Lehr, C.M. Farnesylated Glycol Chitosan as a Platform for Drug Delivery: Synthesis, Characterization, and Investigation of Mucus-Particle Interactions. Biomacromolecules 2018, 19, 3489-3501. [CrossRef]

24. Ali, A.; Ahmed, S. A review on chitosan and its nanocomposites in drug delivery. Int. J. Bio. Macromol. 2018, 109, 273-286. [CrossRef] 
25. Martinez-Martinez, M.; Rodriguez-Berna, G.; Gonzalez-Alvarez, I.; Hernandez, M.J.; Corma, A.; Bermejo, M.; Merino, V.; Gonzalez-Alvarez, M. Ionic Hydrogel Based on Chitosan Cross-Linked with 6-Phosphogluconic Trisodium Salt as a Drug Delivery System. Biomacromolecules 2018, 19, 1294-1304. [CrossRef] [PubMed]

26. Yan, Q.X.; Chen, X.M.; Gong, H.Z.; Qiu, P.; Xiao, X.; Dang, S.Y.; Hong, A.; Ma, Y. Delivery of a TNF-derived peptide by nanoparticles enhances its antitumor activity by inducing cell-cycle arrest and caspase-dependent apoptosis. Faseb J. 2018, 32, 6948-6964. [CrossRef]

27. Xiao, B.; Chen, Q.B.; Zhang, Z.; Wang, L.X.; Kang, Y.J.; Denning, T.; Merlin, D. TNF alpha gene silencing mediated by orally targeted nanoparticles combined with interleukin-22 for synergistic combination therapy of ulcerative colitis. J. Control. Release 2018, 287, 235-246. [CrossRef] [PubMed]

28. Muzzarelli, R.A.A. Chitin, 1st ed.; Pergamon: Oxford, UK, 1977; pp. 51-55.

29. Kou, S.G.; Peters, L.M.; Mucalo, M.R. Chitosan: A review of sources and preparation methods. Int. J. Biol. Macromol. 2021, 169, 85-94. [CrossRef]

30. No, H.K.; Meyers, S.P. Preparation and Characterization of Chitin and Chitosan-A Review. J. Aquat. Food Prod. Technol. 1995, 4, 27-52. [CrossRef]

31. Younes, I.; Rinaudo, M. Chitin and Chitosan Preparation from Marine Sources. Structure, Properties and Applications. Marine Drugs 2015, 13, 1133-1174. [CrossRef]

32. Mao, S.R.; Sun, W.; Kissel, T. Chitosan-based formulations for delivery of DNA and siRNA. Adv. Drug Deliver. Rev. 2010, 62, 12-27. [CrossRef]

33. Wang, S.H.; Xu, T.; Yang, Y.H.; Shao, Z.Z. Colloidal Stability of Silk Fibroin Nanoparticles Coated with Cationic Polymer for Effective Drug Delivery. ACS Appl. Mater. Inter. 2015, 7, 21254-21262. [CrossRef]

34. Lin, J.Y.; Li, Y.; Li, Y.X.; Wu, H.J.; Yu, F.; Zhou, S.F.; Xie, L.Y.; Luo, F.H.; Lin, C.J.; Hou, Z.Q. Drug/Dye-Loaded, Multifunctional PEG-Chitosan-Iron Oxide Nanocomposites for Methotraxate Synergistically Self-Targeted Cancer Therapy and Dual Model Imaging. Acs. Appl. Mater. Inter. 2015, 7, 11908-11920. [CrossRef]

35. Ahsan, S.M.; Thomas, M.; Reddy, K.K.; Sooraparaju, S.G.; Asthana, A.; Bhatnagar, I. Chitosan as biomaterial in drug delivery and tissue engineering. Int. J. Bio. Macromol. 2018, 110, 97-109. [CrossRef]

36. Dobhal, A.; Bangde, P.; Dey, A.; Dandekar, P.; Jain, R. Chitosan-Based Nanoparticulate Systems: Implication Towards Therapeutics Application. In Particulate Technology for Delivery of Therapeutics; Jana, S., Ed.; Springer: Singapore, 2017; pp. 167-225. [CrossRef]

37. Ahmed, T.A.; Aljaeid, B.M. Preparation, characterization, and potential application of chitosan, chitosan derivatives, and chitosan metal nanoparticles in pharmaceutical drug delivery. Drug Des. Devel. Ther. 2016, 10, 483-507. [CrossRef] [PubMed]

38. Mohammed, M.A.; Syeda, J.T.M.; Wasan, K.M.; Wasan, E.K. An Overview of Chitosan Nanoparticles and Its Application in Non-Parenteral Drug Delivery. Pharmaceutics 2017, 9, 53. [CrossRef]

39. Li, J.H.; Cai, C.; Li, J.R.; Li, J.; Li, J.; Sun, T.T.; Wang, L.H.; Wu, H.T.; Yu, G.L. Chitosan-Based Nanomaterials for Drug Delivery. Molecules 2018, 23, 2661. [CrossRef]

40. Sarmento, B.; Ribeiro, A.; Veiga, F.; Ferreira, D. Development and characterization of new insulin containing polysaccharide nanoparticles. Colloid Surface B 2006, 53, 193-202. [CrossRef] [PubMed]

41. Sarmento, B.; Martins, S.; Ribeiro, A.; Veiga, F.; Neufeld, R.; Ferreira, D. Development and comparison of different nanoparticulate polyelectrolyte complexes as insulin carriers. Int. J. Pept. Res. Ther. 2006, 12, 131-138. [CrossRef]

42. Yang, S.J.; Lin, F.H.; Tsai, H.M.; Lin, C.F.; Chin, H.C.; Wong, J.M.; Shieh, M.J. Alginate-folic acid-modified chitosan nanoparticles for photodynamic detection of intestinal neoplasms. Biomaterials 2011, 32, 2174-2182. [CrossRef]

43. Grenha, A.; Gomes, M.E.; Rodrigues, M.; Santo, V.E.; Mano, J.F.; Neves, N.M.; Reis, R.L. Development of new chitosan/carrageenan nanoparticles for drug delivery applications. J. Biomed. Mater. Res. Part A 2010, 92, 1265-1272. [CrossRef] [PubMed]

44. Avadi, M.R.; Sadeghi, A.M.M.; Mohammadpour, N.; Abedin, S.; Atyabi, F.; Dinarvand, R.; Rafiee-Tehrani, M. Preparation and characterization of insulin nanoparticles using chitosan and Arabic gum with ionic gelation method. Nanomed.-Nanotechnol. Biol. Med. 2010, 6, 58-63. [CrossRef]

45. Du, J.; Sun, R.; Zhang, S.; Govender, T.; Zhang, L.F.; Xiong, C.D.; Peng, Y.X. Novel polyelectrolyte carboxymethyl konjac glucomannan-chitosan nanoparticles for drug delivery. Macromol. Rapid Commun. 2004, 25, 954-958. [CrossRef]

46. Kaihara, S.; Suzuki, Y.; Fujimoto, K. In situ synthesis of polysaccharide nanoparticles via polyion complex of carboxymethyl cellulose and chitosan. Colloid Surface B 2011, 85, 343-348. [CrossRef] [PubMed]

47. Yeh, M.K.; Cheng, K.M.; Hu, C.S.; Huang, Y.C.; Young, J.J. Novel protein-loaded chondroitin sulfate-chitosan nanoparticles: Preparation and characterization. Acta. Biomater. 2011, 7, 3804-3812. [CrossRef] [PubMed]

48. Grabnar, P.A.; Kristl, J. Physicochemical characterization of protein-loaded pectin-chitosan nanoparticles prepared by polyelectrolyte complexation. Pharmazie 2010, 65, 851-852. [CrossRef]

49. Liu, Z.G.; Jiao, Y.P.; Liu, F.N.; Zhang, Z.Y. Heparin/chitosan nanoparticle carriers prepared by polyelectrolyte complexation. J. Biomed. Mater. Res. Part A 2007, 83, 806-812. [CrossRef]

50. De la Fuente, M.; Seijo, B.; Alonso, M.J. Novel hyaluronic acid-chitosan nanoparticles for ocular gene therapy. Invest. Ophthalmol. Vis. Sci. 2008, 49, 2016-2024. [CrossRef]

51. Elsayed, A.; Al-Remawi, M.; Qinna, N.; Farouk, A.; Al-Sou'od, K.A.; Badwan, A.A. Chitosan-Sodium Lauryl Sulfate Nanoparticles as a Carrier System for the In Vivo Delivery of Oral Insulin. Aaps. Pharmscitech. 2011, 12, 958-964. [CrossRef] 
52. Teijeiro-Osorio, D.; Remunan-Lopez, C.; Alonso, M.J. New Generation of Hybrid Poly/Oligosaccharide Nanoparticles as Carriers for the Nasal Delivery of Macromolecules. Biomacromolecules 2009, 10, 243-249. [CrossRef]

53. Lin, Y.H.; Mi, F.L.; Chen, C.T.; Chang, W.C.; Peng, S.F.; Liang, H.F.; Sung, H.W. Preparation and characterization of nanoparticles shelled with chitosan for oral insulin delivery. Biomacromolecules 2007, 8, 146-152. [CrossRef]

54. Lin, Y.H.; Sonaje, K.; Lin, K.M.; Juang, J.H.; Mi, F.L.; Yang, H.W.; Sung, H.W. Multi-ion-crosslinked nanoparticles with pHresponsive characteristics for oral delivery of protein drugs. J. Control. Release 2008, 132, 141-149. [CrossRef] [PubMed]

55. Hu, Y.; Jiang, X.; Ding, Y.; Ge, H.; Yuan, Y.; Yang, C. Synthesis and characterization of chitosan-poly(acrylic acid) nanoparticles. Biomaterials 2002, 23, 3193-3201. [CrossRef]

56. Bayat, A.; Larijani, B.; Ahmadian, S.; Junginger, H.E.; Rafiee-Tehrani, M. Preparation and characterization of insulin nanoparticles using chitosan and its quaternized derivatives. Nanomed.-Nanotechnol. Biol. Med. 2008, 4, 115-120. [CrossRef]

57. Erbacher, P.; Zou, S.; Bettinger, T.; Steffan, A.M.; Remy, J.S. Chitosan-based vector/DNA complexes for gene delivery: Biophysical characteristics and transfection ability. Pharm Res 1998, 15, 1332-1339. [CrossRef] [PubMed]

58. Xu, J.; Dai, W.; Wang, Z.; Chen, B.; Li, Z.; Fan, X. Intranasal vaccination with chitosan-DNA nanoparticles expressing pneumococcal surface antigen a protects mice against nasopharyngeal colonization by Streptococcus pneumoniae. Clin. Vaccine Immunol. 2011, 18, 75-81. [CrossRef] [PubMed]

59. Goycoolea, F.M.; Lollo, G.; Remunan-Lopez, C.; Quaglia, F.; Alonso, M.J. Chitosan-alginate blended nanoparticles as carriers for the transmucosal delivery of macromolecules. Biomacromolecules 2009, 10, 1736-1743. [CrossRef]

60. Alonso-Sande, M.; Cuna, M.; Remunan-Lopez, C. Formation of new glucomannan-chitosan nanoparticles and study of their ability to associate and deliver proteins. Macromolecules 2006, 39, 4152-4158. [CrossRef]

61. Ohya, Y.; Shiratani, M.; Kobayashi, H.; Ouchi, T. Release Behavior of 5-Fluorouracil from Chitosan-Gel Nanospheres Immobilizing 5-Fluorouracil Coated with Polysaccharides and Their Cell-Specific Cytotoxicity. J. Macromol. Sci.-Pure Appl. Chem. 1994, 31, 629-642. [CrossRef]

62. Tokumitsu, H.; Ichikawa, H.; Fukumori, Y.; Block, L.H. Preparation of gadopentetic acid-loaded chitosan microparticles for gadolinium neutron-capture therapy of cancer by a novel emulsion-droplet coalescence technique. Chem. Pharm. Bull. 1999, 47, 838-842. [CrossRef]

63. El-Shabouri, M.H. Positively charged nanoparticles for improving the oral bioavailability of cyclosporin-A. Int. J. Pharmaceut. 2002, 249, 101-108. [CrossRef]

64. Mitra, S.; Gaur, U.; Ghosh, P.C.; Maitra, A.N. Tumour targeted delivery of encapsulated dextran-doxorubicin conjugate using chitosan nanoparticles as carrier. J. Control. Release 2001, 74, 317-323. [CrossRef]

65. Calvo, P.; RemunanLopez, C.; VilaJato, J.L.; Alonso, M.J. Novel hydrophilic chitosan-polyethylene oxide nanoparticles as protein carriers. J. Appl. Polym. Sci. 1997, 63, 125-132. [CrossRef]

66. Tian, X.X.; Groves, M.J. Formulation and biological activity of antineoplastic proteoglycans derived from Mycobacterium vaccae in chitosan nanoparticles. J. Pharm. Pharmacol. 1999, 51, 151-157. [CrossRef]

67. Chan, H.K.; Kwok, P.C.L. Production methods for nanodrug particles using the bottom-up approach. Adv. Drug Deliv. Rev. 2011, 63, 406-416. [CrossRef]

68. Wang, J.; Byrne, J.D.; Napier, M.E.; DeSimone, J.M. More Effective Nanomedicines through Particle Design. Small 2011, 7, 1919-1931. [CrossRef] [PubMed]

69. Hu, L.M.; Sun, Y.; Wu, Y. Advances in chitosan-based drug delivery vehicles. Nanoscale 2013, 5, 3103-3111. [CrossRef]

70. Kawashima, Y.; Handa, T.; Kasai, A.; Takenaka, H.; Lin, S.Y.; Ando, Y. Novel method for the preparation of controlled-release theophylline granules coated with a polyelectrolyte complex of sodium polyphosphate-chitosan. J. Pharm. Sci. 1985, 74, 264-268. [CrossRef]

71. Bhattarai, N.; Ramay, H.R.; Chou, S.H.; Zhang, M. Chitosan and lactic acid-grafted chitosan nanoparticles as carriers for prolonged drug delivery. Int. J. Nanomedicine 2006, 1, 181-187. [CrossRef] [PubMed]

72. Grenha, A. Chitosan nanoparticles: A survey of preparation methods. J. Drug Target. 2012, 20, 291-300. [CrossRef]

73. Zhang, S.J.; Wu, L.X. Amyloid-Beta Associated with Chitosan Nano-Carrier has Favorable Immunogenicity and Permeates the BBB. Aaps. Pharmscitech. 2009, 10, 900-905. [CrossRef]

74. Ngan, L.T.K.; Wang, S.L.; Hiep, D.M.; Luong, P.M.; Vui, N.T.; Dinh, T.M.; Dzung, N.A. Preparation of chitosan nanoparticles by spray drying, and their antibacterial activity. Res. Chem. Intermed. 2014, 40, 2165-2175. [CrossRef]

75. Sinsuebpol, C.; Chatchawalsaisin, J.; Kulvanich, P. Preparation and in vivo absorption evaluation of spray dried powders containing salmon calcitonin loaded chitosan nanoparticles for pulmonary delivery. Drug. Des. Dev. Ther. 2013, 7, 861-873. [CrossRef]

76. Li, F.Q.; Ji, R.R.; Chen, X.; You, B.M.; Pan, Y.H.; Su, J.C. Cetirizine Dihydrochloride Loaded Microparticles Design Using Ionotropic Cross-linked Chitosan Nanoparticles by Spray-drying Method. Arch. Pharm. Res. 2010, 33, 1967-1973. [CrossRef]

77. Mehrotra, A.; Nagarwal, R.C.; Pandit, J.K. Fabrication of Lomustine Loaded Chitosan Nanoparticles by Spray Drying and in Vitro Cytostatic Activity on Human Lung Cancer Cell Line L132. J. Nanomed. Nanotechnol. 2010, 1, 1-7. [CrossRef]

78. Tokumitsu, H.; Ichikawa, H.; Fukumori, Y. Chitosan-gadopentetic acid complex nanoparticles for gadolinium neutron-capture therapy of cancer: Preparation by novel emulsion-droplet coalescence technique and characterization. Pharm. Res. 1999, 16, 1830-1835. [CrossRef] 
79. Reddy, Y.D.; Dhachinamoorthi, D. Formulation and in vitro evaluation of antineoplastic drug loaded nanoparticles as drug delivery system. Afr. J. Pharm. Pharmacol. 2013, 7, 1592-1604. [CrossRef]

80. Niwa, T.; Takeuchi, H.; Hino, T.; Kunou, N.; Kawashima, Y. Preparations of Biodegradable Nanospheres of Water-Soluble and Insoluble Drugs with D,L-Lactide Glycolide Copolymer by a Novel Spontaneous Emulsification Solvent Diffusion Method, and the Drug Release Behavior. J. Control. Release 1993, 25, 89-98. [CrossRef]

81. Luque-Alcaraz, A.G.; Lizardi-Mendoza, J.; Goycoolea, F.M.; Higuera-Ciapara, I.; Arguelles-Monal, W. Preparation of chitosan nanoparticles by nanoprecipitation and their ability as a drug nanocarrier. Rsc Adv 2016, 6, 59250-59256. [CrossRef]

82. Melo, E.P.; Aires-Barros, M.R.; Cabral, J.M. Reverse micelles and protein biotechnology. Biotechnol. Annu. Rev. 2001, 7, 87-129. [CrossRef]

83. Pileni, M.P. Reverse micelles used as templates: A new understanding in nanocrystal growth. J. Exp. Nanosci. 2006, 1, 13-27. [CrossRef]

84. Banerjee, T.; Mitra, S.; Singh, A.K.; Sharma, R.K.; Maitra, A. Preparation, characterization and biodistribution of ultrafine chitosan nanoparticles. Int. J. Pharmaceut. 2002, 243, 93-105. [CrossRef]

85. Kafshgari, M.H.; Khorram, M.; Mansouri, M.; Samimi, A.; Osfouri, S. Preparation of alginate and chitosan nanoparticles using a new reverse micellar system. Iran Polym. J. 2012, 21, 99-107. [CrossRef]

86. Alonso, M.J. Nanoparticulate drug carrier technology. In Microparticulate systems for the delivery of proteins and vaccines; Cohen, S., Bernstein, H., Eds.; Marcel Dekker: New York, NY, USA, 1996; pp. 203-242.

87. Janes, K.A.; Calvo, P.; Alonso, M.J. Polysaccharide colloidal particles as delivery systems for macromolecules. Adv. Drug Deliver. Rev. 2001, 47, 83-97. [CrossRef]

88. Poncelet, D. Microencapsulation: Fundamentals, methods and applications. In Surface chemistry in biomedical and environmental science; Blitz, J.P., Gun'ko, V.M., Eds.; Springer: Dordrecht, The Netherlands, 2006; pp. 23-24.

89. Sajeesh, S.; Sharma, C.P. Cyclodextrin-insulin complex encapsulated polymethacrylic acid based nanoparticles for oral insulin delivery. Int. J. Pharm. 2006, 325, 147-154. [CrossRef] [PubMed]

90. Sajeesh, S.; Sharma, C.P. Novel pH responsive polymethacrylic acid-chitosan-polyethylene glycol nanoparticles for oral peptide delivery. J. Biomed. Mater. Res. B. Appl. Biomater. 2006, 76, 298-305. [CrossRef]

91. Janes, K.A.; Fresneau, M.P.; Marazuela, A.; Fabra, A.; Alonso, M.J. Chitosan nanoparticles as delivery systems for doxorubicin. J. Control. Release 2001, 73, 255-267. [CrossRef]

92. Terbojevich, M.; Muzzarelli, R.A.A. Chitosan. In Handbook of hydrocolloids; Phillips, G.O., Williams, P.A., Eds.; Woodhead Publishing Ltd.: Cambridge, UK, 2009; pp. 367-378.

93. Mao, H.Q.; Roy, K.; Troung-Le, V.L.; Janes, K.A.; Lin, K.Y.; Wang, Y.; August, J.T.; Leong, K.W. Chitosan-DNA nanoparticles as gene carriers: Synthesis, characterization and transfection efficiency. J. Control. Release 2001, 70, 399-421. [CrossRef]

94. Li, P.W.; Wang, G.; Yang, Z.M.; Duan, W.; Peng, Z.; Kong, L.X.; Wang, Q.H. Development of drug-loaded chitosan-vanillin nanoparticles and its cytotoxicity against HT-29 cells. Drug Deliv. 2016, 23, 30-35. [CrossRef]

95. Wang, G.; Li, P.; Peng, Z. Formulation of vanillin cross-linked chitosan nanoparticles and its characterization. Adv. Mater. Res. 2011, 2, 474-477. [CrossRef]

96. Prabaharan, M. Chitosan-based nanoparticles for tumor-targeted drug delivery. Int. J. Biol. Macromol. 2015, 72, 1313-1322. [CrossRef]

97. Yang, X.; Zhang, Q.; Wang, Y.; Chen, H.; Zhang, H.; Gao, F.; Liu, L. Self-aggregated nanoparticles from methoxy poly(ethylene glycol)-modified chitosan: Synthesis; characterization; aggregation and methotrexate release in vitro. Colloids Surf. B Biointerfaces 2008, 61, 125-131. [CrossRef]

98. Wang, Y.S.; Liu, L.R.; Jiang, Q.; Zhang, Q.Q. Self-aggregated nanoparticles of cholesterol-modified chitosan conjugate as a novel carrier of epirubicin. Eur. Polym. J. 2007, 43, 43-51. [CrossRef]

99. Anitha, A.; Deepagan, V.G.; Rani, V.V.D.; Menon, D.; Nair, S.V.; Jayakumar, R. Preparation, characterization, in vitro drug release and biological studies of curcumin loaded dextran sulphate-chitosan nanoparticles. Carbohydr. Polym. 2011, 84, 1158-1164. [CrossRef]

100. Anitha, A.; Maya, S.; Deepa, N.; Chennazhi, K.P.; Nair, S.V.; Jayakumar, R. Curcumin-Loaded N,O-Carboxymethyl Chitosan Nanoparticles for Cancer Drug Delivery. J. Biomater. Sci.-Polym. Ed. 2012, 23, 1381-1400. [CrossRef]

101. Zheng, Y.; Yang, W.; Wang, C.; Hu, J.; Fu, S.; Dong, L.; Wu, L.; Shen, X. Nanoparticles based on the complex of chitosan and polyaspartic acid sodium salt: Preparation, characterization and the use for 5-fluorouracil delivery. Eur. J. Pharm. Biopharm. 2007, 67, 621-631. [CrossRef] [PubMed]

102. Anitha, A.; Chennazhi, K.P.; Nair, S.V.; Jayakumar, R. 5-Flourouracil Loaded N,O-Carboxymethyl Chitosan Nanoparticles as an Anticancer Nanomedicine for Breast Cancer. J. Biomed. Nanotechnol. 2012, 8, 29-42. [CrossRef] [PubMed]

103. Cha, J.; Lee, W.B.; Park, C.R.; Cho, Y.W.; Ahn, C.H.; Kwon, I.C. Preparation and characterization of cisplatin-incorporated chitosan hydrogels, microparticles, and nanoparticles. Macromol. Res. 2006, 14, 573-578. [CrossRef]

104. Bilensoy, E.; Sarisozen, C.; Esendagli, G.; Dogan, A.L.; Aktas, Y.; Sen, M.; Mungan, N.A. Intravesical cationic nanoparticles of chitosan and polycaprolactone for the delivery of Mitomycin C to bladder tumors. Int. J. Pharmaceut. 2009, 371, 170-176. [CrossRef] [PubMed]

105. Li, F.; Li, J.N.; Wen, X.J.; Zhou, S.H.; Tong, X.W.; Su, P.P.; Li, H.; Shi, D.L. Anti-tumor activity of paclitaxel-loaded chitosan nanoparticles: An in vitro study. Mat. Sci. Eng. C-Mater. 2009, 29, 2392-2397. [CrossRef] 
106. Vivek, R.; Babu, V.N.; Thangam, R.; Subramanian, K.S.; Kannan, S. pH-responsive drug delivery of chitosan nanoparticles as Tamoxifen carriers for effective anti-tumor activity in breast cancer cells. Colloid Sur. B 2013, 111, 117-123. [CrossRef]

107. Hwang, H.Y.; Kim, I.S.; Kwon, I.C.; Kim, Y.H. Tumor targetability and antitumor effect of docetaxel-loaded hydrophobically modified glycol chitosan nanoparticles. J. Control. Release 2008, 128, 23-31. [CrossRef]

108. Zhang, X.Q.; Zhang, H.; Yin, L.Q.; Hu, R.; Qiu, T.; Yin, Y.H.; Xiong, X.; Zheng, H.; Wang, Q. A pH-Sensitive Nanosystem Based on Carboxymethyl Chitosan for Tumor-Targeted Delivery of Daunorubicin. J. Biomed. Nanotechnol. 2016, 12, 1688-1698. [CrossRef] [PubMed]

109. Zheng, H.; Yin, L.Q.; Zhang, X.Q.; Zhang, H.; Hu, R.; Yin, Y.H.; Qiu, T.; Xiong, X.; Wang, Q. Redox Sensitive Shell and Core Crosslinked Hyaluronic Acid Nanocarriers for Tumor-Targeted Drug Delivery. J. Biomed. Nanotechnol. 2016, 12, 1641-1653. [CrossRef] [PubMed]

110. Hu, R.; Zheng, H.; Cao, J.; Davoudi, Z.; Wang, Q. Synthesis and In Vitro Characterization of Carboxymethyl Chitosan-CBADoxorubicin Conjugate Nanoparticles as pH-Sensitive Drug Delivery Systems. J. Biomed. Nanotechnol. 2017, 13, 1097-1105. [CrossRef] [PubMed]

111. Liu, M.; Zhang, J.; Shan, W.; Huang, Y. Developments of mucus penetrating nanoparticles. Asian J. Pharm. Sci. 2015, 10, $275-282$. [CrossRef]

112. Lavelle, E. Targeted mucosal delivery of drugs and vaccines. Expert Opin. Ther. Pat. 2000, 10, 179-190. [CrossRef]

113. Van der Lubben, I.M.; Verhoef, J.C.; Borchard, G.; Junginger, H.E. Chitosan for mucosal vaccination. Adv. Drug Deliver. Rev. 2001, 52, 139-144. [CrossRef]

114. Vila, A.; Sanchez, A.; Tobio, M.; Calvo, P.; Alonso, M.J. Design of biodegradable particles for protein delivery. J. Control. Release 2002, 78, 15-24. [CrossRef]

115. De Campos, A.M.; Sanchez, A.; Alonso, M.J. Chitosan nanoparticles: A new vehicle for the improvement of the delivery of drugs to the ocular surface. Application to cyclosporin A. Int. J. Pharmaceut. 2001, 224, 159-168. [CrossRef]

116. Roy, K.; Mao, H.Q.; Huang, S.K.; Leong, K.W. Oral gene delivery with chitosan-DNA nanoparticles generates immunologic protection in a murine model of peanut allergy. Nat. Med. 1999, 5, 387-391. [CrossRef]

117. Motwani, S.K.; Chopra, S.; Talegaonkar, S.; Kohl, K.; Ahmad, F.J.; Khar, R.K. Chitosan-sodium alginate nanoparticles as submicroscopic reservoirs for ocular delivery: Formulation, optimisation and in vitro characterisation. Eur. J. Pharm. Biopharm. 2008, 68, 513-525. [CrossRef] [PubMed]

118. Baltzley, S.; Mohammad, A.; Malkawi, A.H.; Al-Ghananeem, A.M. Intranasal Drug Delivery of Olanzapine-Loaded Chitosan Nanoparticles. Aaps. Pharmscitech. 2014, 15, 1598-1602. [CrossRef] [PubMed]

119. Al-Ghananeem, A.M.; Saeed, H.; Florence, R.; Yokel, R.A.; Malkawi, A.H. Intranasal drug delivery of didanosine-loaded chitosan nanoparticles for brain targeting; an attractive route against infections caused by AIDS viruses. J. Drug Target. 2010, 18, 381-388. [CrossRef]

120. Park, I.K.; Park, Y.H.; Shin, B.A.; Choi, E.S.; Kim, Y.R.; Akaike, T.; Cho, C.S. Galactosylated chitosan-graft-dextran as hepatocytetargeting DNA carrier. J. Control. Release 2000, 69, 97-108. [CrossRef]

121. Illum, L.; Jabbal-Gill, I.; Hinchcliffe, M.; Fisher, A.N.; Davis, S.S. Chitosan as a novel nasal delivery system for vaccines. Adv. Drug Deliver. Rev. 2001, 51, 81-96. [CrossRef]

122. Amidi, M.; Romeijn, S.G.; Verhoef, J.C.; Junginger, H.E.; Bungener, L.; Huckriede, A.; Crommelin, D.J.A.; Jiskoot, W. N-Trimethyl chitosan (TMC) nanoparticles loaded with influenza subunit antigen for intranasal vaccination: Biological properties and immunogenicity in a mouse model. Vaccine 2007, 25, 144-153. [CrossRef] [PubMed]

123. Boonyo, W.; Junginger, H.E.; Waranuch, N.; Polnok, A.; Pitaksuteepong, T. Chitosan and trimethyl chitosan chloride (TMC) as adjuvants for inducing immune responses to ovalbumin in mice following nasal administration. J. Control. Release 2007, 121, 168-175. [CrossRef]

124. Svirshchevskaya, E.V.; Alekseeva, L.G.; Reshetov, P.D.; Phomicheva, N.N.; Parphenyuk, S.A.; Ilyina, A.V.; Zueva, V.S.; Lopatin, S.A.; Levov, A.N.; Varlamov, V.P. Mucoadjuvant properties of lipo- and glycoconjugated derivatives of oligochitosans. Eur. J. Med. Chem. 2009, 44, 2030-2037. [CrossRef] [PubMed]

125. Sayin, B.; Somavarapu, S.; Li, X.W.; Thanou, M.; Sesardic, D.; Alpar, H.O.; Senel, S. Mono-N-carboxymethyl chitosan (MCC) and $\mathrm{N}$-trimethyl chitosan (TMC) nanoparticles for non-invasive vaccine delivery. Int. J. Pharmaceut. 2008, 363, 139-148. [CrossRef]

126. Borges, O.; Cordeiro-da-Silva, A.; Tavares, J.; Santarem, N.; De Sousa, A.; Borchard, G.; Junginger, H.E. Immune response by nasal delivery of hepatitis B surface antigen and codelivery of a CpG ODN in alginate coated chitosan nanoparticles. Eur. J. Pharm. Biopharm. 2008, 69, 405-416. [CrossRef]

127. Klas, S.D.; Petrie, C.R.; Warwood, S.J.; Williams, M.S.; Olds, C.L.; Stenz, J.P.; Cheff, A.M.; Hinchcliffe, M.; Richardson, C.; Wimer, S. A single immunization with a dry powder anthrax vaccine protects rabbits against lethal aerosol challenge. Vaccine 2008, 26, 5494-5502. [CrossRef]

128. Frank, M.; Schloissnig, S. Bioinformatics and molecular modeling in glycobiology. Cell Mol. Life Sci. 2010, 67, $2749-2772$. [CrossRef]

129. Baudner, B.C.; Giuliani, M.M.; Verhoef, J.C.; Rappuoli, R.; Junginger, H.E.; Del Giudice, G. The concomitant use of the LTK63 mucosal adjuvant and of chitosan-based delivery system enhances the immunogenicity and efficacy of intranasally administered vaccines. Vaccine 2003, 21, 3837-3844. [CrossRef] 
130. Amidi, M.; Mastrobattista, E.; Jiskoot, W.; Hennink, W.E. Chitosan-based delivery systems for protein therapeutics and antigens. Adv. Drug Deliv. Rev. 2010, 62, 59-82. [CrossRef]

131. Cui, Z.; Mumper, R.J. Chitosan-based nanoparticles for topical genetic immunization. J. Control. Release 2001, 75, 409-419. [CrossRef]

132. Madrigal-Carballo, S.; Esquivel, M.; Sibaja, M. Protein-loaded chitosan nanoparticles modulate uptake and antigen presentation of hen egg-white lysozyme by murine peritoneal macrophages. Int. J. Nanoparticles 2010, 3, 179-191. [CrossRef]

133. Xu, W.; Shen, Y.; Jiang, Z.; Wang, Y.; Chu, Y.; Xiong, S. Intranasal delivery of chitosan-DNA vaccine generates mucosal SIgA and anti-CVB3 protection. Vaccine 2004, 22, 3603-3612. [CrossRef]

134. Smitha, K.T.; Sreelakshmi, M.; Nisha, N.; Jayakumar, R.; Biswas, R. Amidase encapsulated O-carboxymethyl chitosan nanoparticles for vaccine delivery. Int. J. Biol. Macromol. 2014, 63, 154-157. [CrossRef] [PubMed]

135. Pattani, A.; Patravale, V.B.; Panicker, L.; Potdar, P.D. Immunological Effects and Membrane Interactions of Chitosan Nanoparticles. Mol. Pharmaceut. 2009, 6, 345-352. [CrossRef]

136. Jamil, B.; Habib, H.; Abbasi, S.; Nasir, H.; Rahman, A.; Rehman, A.; Bokhari, H.; Imran, M. Cefazolin loaded chitosan nanoparticles to cure multi drug resistant Gram-negative pathogens. Carbohydr. Polym. 2016, 136, 682-691. [CrossRef] [PubMed]

137. Dube, A.; Reynolds, J.L.; Law, W.C.; Maponga, C.C.; Prasad, P.N.; Morse, G.D. Multimodal nanoparticles that provide immunomodulation and intracellular drug delivery for infectious diseases. Nanomed.-Nanotechnol. Biol. Med. 2014, 10, 831-838. [CrossRef]

138. Garg, T.; Rath, G.; Goyal, A.K. Inhalable chitosan nanoparticles as antitubercular drug carriers for an effective treatment of tuberculosis. Artif. Cell. Nanomed. Biotechnol. 2016, 44, 997-1001. [CrossRef]

139. Moretton, M.A.; Chiappetta, D.A.; Andrade, F.; Das Neves, J.; Ferreira, D.; Sarmento, B.; Sosnik, A. Hydrolyzed GalactomannanModified Nanoparticles and Flower-Like Polymeric Micelles for the Active Targeting of Rifampicin to Macrophages. J. Biomed. Nanotechnol. 2013, 9, 1076-1087. [CrossRef] [PubMed]

140. Junise, V.; Saraswathi, R. Development and characterization of inhaled chitosan nanoparticles loaded with Isoniazid. J. pharm. technol. res. manag. 2014, 2, 159-170. [CrossRef]

141. Maya, S.; Indulekha, S.; Sukhithasri, V.; Smitha, K.T.; Nair, S.V.; Jayakumar, R.; Biswas, R. Efficacy of tetracycline encapsulated O-carboxymethyl chitosan nanoparticles against intracellular infections of Staphylococcus aureus. Int. J. Biol. Macromol. 2012, 51, 392-399. [CrossRef] [PubMed]

142. Jain, V.; Gupta, A.; Pawar, V.K.; Asthana, S.; Jaiswal, A.K.; Dube, A.; Chourasia, M.K. Chitosan-assisted immunotherapy for intervention of experimental leishmaniasis via amphotericin B-loaded solid lipid nanoparticles. Appl. Biochem. Biotechnol. 2014, 174, 1309-1330. [CrossRef]

143. Zhou, W.; Wang, Y.; Jian, J.; Song, S. Self-aggregated nanoparticles based on amphiphilic poly(lactic acid)-grafted-chitosan copolymer for ocular delivery of amphotericin B. Int. J. Nanomedicine 2013, 8, 3715-3728. [CrossRef]

144. Chhonker, Y.S.; Prasad, Y.D.; Chandasana, H.; Vishvkarma, A.; Mitra, K.; Shukla, P.K.; Bhatta, R.S. Amphotericin-B entrapped lecithin/chitosan nanoparticles for prolonged ocular application. Int. J. Biol. Macromol. 2015, 72, 1451-1458. [CrossRef]

145. Kong, Z.Q.; Yu, M.F.; Cheng, K.; Weng, W.J.; Wang, H.M.; Lin, J.; Du, P.Y.; Han, G.R. Incorporation of chitosan nanospheres into thin mineralized collagen coatings for improving the antibacterial effect. Colloid Surf. B 2013, 111, 536-541. [CrossRef] [PubMed]

146. Pornpattananangkul, D.; Zhang, L.; Olson, S.; Aryal, S.; Obonyo, M.; Vecchio, K.; Huang, C.M.; Zhang, L.F. Bacterial ToxinTriggered Drug Release from Gold Nanoparticle-Stabilized Liposomes for the Treatment of Bacterial Infection. J. Am. Chem. Soc. 2011, 133, 4132-4139. [CrossRef] [PubMed]

147. Costa, J.R.; Silva, N.C.; Sarmento, B.; Pintado, M. Potential chitosan-coated alginate nanoparticles for ocular delivery of daptomycin. Eur. J. Clin. Microbiol. Infect. Dis. 2015, 34, 1255-1262. [CrossRef] [PubMed]

148. Ustundag-Okur, N.; Gokce, E.H.; Bozbiyik, D.I.; Egrilmez, S.; Ozer, O.; Ertan, G. Preparation and in vitro-in vivo evaluation of ofloxacin loaded ophthalmic nano structured lipid carriers modified with chitosan oligosaccharide lactate for the treatment of bacterial keratitis. Eur. J. Pharm. Sci. 2014, 63, 204-215. [CrossRef]

149. Lin, Y.H.; Tsai, S.C.; Lai, C.H.; Lee, C.H.; He, Z.S.; Tseng, G.C. Genipin-cross-linked fucose-chitosan/heparin nanoparticles for the eradication of Helicobacter pylori. Biomaterials 2013, 34, 4466-4479. [CrossRef] [PubMed]

150. Bivas-Benita, M.; Van Meijgaarden, K.E.; Franken, K.L.; Junginger, H.E.; Borchard, G.; Ottenhoff, T.H.; Geluk, A. Pulmonary delivery of chitosan-DNA nanoparticles enhances the immunogenicity of a DNA vaccine encoding HLA-A*0201-restricted T-cell epitopes of Mycobacterium tuberculosis. Vaccine 2004, 22, 1609-1615. [CrossRef]

151. Cota-Arriola, O.; Cortez-Rocha, M.O.; Burgos-Hernandez, A.; Ezquerra-Brauer, J.M.; Plascencia-Jatomea, M. Controlled release matrices and micro/nanoparticles of chitosan with antimicrobial potential: Development of new strategies for microbial control in agriculture. J. Sci. Food Agric. 2013, 93, 1525-1536. [CrossRef]

152. Hua, S.; Marks, E.; Schneider, J.J.; Keely, S. Advances in oral nano-delivery systems for colon targeted drug delivery in inflammatory bowel disease: Selective targeting to diseased versus healthy tissue. Nanomed.-Nanotechnol. Biol. Med. 2015, 11, 1117-1132. [CrossRef] [PubMed]

153. Bagre, A.P.; Jain, K.; Jain, N.K. Alginate coated chitosan core shell nanoparticles for oral delivery of enoxaparin: In vitro and in vivo assessment. Int. J. Pharmaceut. 2013, 456, 31-40. [CrossRef] 
154. Tozaki, H.; Odoriba, T.; Okada, N.; Fujita, T.; Terabe, A.; Suzuki, T.; Okabe, S.; Muranishi, S.; Yamamoto, A. Chitosan capsules for colon-specific drug delivery: Enhanced localization of 5-aminosalicylic acid in the large intestine accelerates healing of TNBS-induced colitis in rats. J. Control. Release 2002, 82, 51-61. [CrossRef]

155. Li, P.W.; Wang, Y.C.; Zeng, F.B.; Chen, L.J.; Peng, Z.; Kong, L.X. Synthesis and characterization of folate conjugated chitosan and cellular uptake of its nanoparticles in HT-29 cells. Carbohyd. Res. 2011, 346, 801-806. [CrossRef]

156. Saboktakin, M.R.; Tabatabaie, R.M.; Maharramov, A.; Ramazanov, M.A. Synthesis and in vitro evaluation of carboxymethyl starch-chitosan nanoparticles as drug delivery system to the colon. Int. J. Biol. Macromol. 2011, 48, 381-385. [CrossRef]

157. Kadiyala, I.; Loo, Y.; Roy, K.; Rice, J.; Leong, K.W. Transport of chitosan-DNA nanoparticles in human intestinal M-cell model versus normal intestinal enterocytes. Eur. J. Pharm. Sci. 2010, 39, 103-109. [CrossRef] [PubMed]

158. Jain, A.; Jain, S.K.; Ganesh, N.; Barve, J.; Beg, A.M. Design and development of ligand-appended polysaccharidic nanoparticles for the delivery of oxaliplatin in colorectal cancer. Nanomedicine 2010, 6, 179-190. [CrossRef] [PubMed]

159. Yang, S.J.; Shieh, M.J.; Lin, F.H.; Lou, P.J.; Peng, C.L.; Wei, M.F.; Yao, C.J.; Lai, P.S.; Young, T.H. Colorectal cancer cell detection by 5-aminolaevulinic acid-loaded chitosan nano-particles. Cancer Lett. 2009, 273, 210-220. [CrossRef]

160. Park, J.S.; Koh, Y.S.; Bang, J.Y.; Jeong, Y.I.; Lee, J.J. Antitumor effect of all-trans retinoic acid-encapsulated nanoparticles of methoxy poly(ethylene glycol)-conjugated chitosan against CT-26 colon carcinoma in vitro. J. Pharm. Sci. 2008, 97, 4011-4019. [CrossRef] [PubMed]

161. Jain, A.; Jain, S.K. In vitro and cell uptake studies for targeting of ligand anchored nanoparticles for colon tumors. Eur. J. Pharm. Sci. 2008, 35, 404-416. [CrossRef] [PubMed]

162. Yuan, X.B.; Li, H.; Yuan, Y.B. Preparation of cholesterol-modified chitosan self-aggregated nanoparticles for delivery of drugs to ocular surface. Carbohyd. Polym. 2006, 65, 337-345. [CrossRef]

163. De Salamanca, A.E.; Diebold, Y.; Calonge, M.; Garcia-Vazquez, C.; Callejo, S.; Vila, A.; Alonso, M.J. Chitosan nanoparticles as a potential drug delivery system for the ocular surface: Toxicity, uptake mechanism and in vivo tolerance. Invest. Ophthalmol. Vis. Sci. 2006, 47, 1416-1425. [CrossRef]

164. Diebold, Y.; Jarrin, M.; Saez, V.; Carvalho, E.L.S.; Orea, M.; Calonge, M.; Seijo, B.; Alonso, M.J. Ocular drug delivery by liposome-chitosan nanoparticle complexes (LCS-NP). Biomaterials 2007, 28, 1553-1564. [CrossRef]

165. Calvo, P.; VilaJato, J.L.; Alonso, M.J. Evaluation of cationic polymer-coated nanocapsules as ocular drug carriers. J. Appl. Polym. Sci. 1997, 153, 41-50. [CrossRef]

166. Calvo, P.; Alonso, M.J.; VilaJato, J.L.; Robinson, J.R. Improved ocular bioavailability of indomethacin by novel ocular drug carriers. J. Pharm. Pharmacol. 1996, 48, 1147-1152. [CrossRef]

167. Kao, H.J.; Lin, H.R.; Lo, Y.L.; Yu, S.P. Characterization of pilocarpine-loaded chitosan/carbopol nanoparticles. J. Pharm. Pharmacol. 2006, 58, 179-186. [CrossRef]

168. Lin, H.R.; Yu, S.P.; Kuo, C.J.; Kao, H.J.; Lo, Y.L.; Lin, Y.J. Pilocarpine-loaded chitosan-PAA nanosuspension for ophthalmic delivery. J. Biomater. Sci.-Polym. Ed. 2007, 18, 205-221. [CrossRef] [PubMed]

169. De la Fuente, M.; Seijo, B.; Alonso, M.J. Bioadhesive hyaluronan-chitosan nanoparticles can transport genes across the ocular mucosa and transfect ocular tissue. Gene Ther. 2008, 15, 668-676. [CrossRef] [PubMed]

170. Qu, X.Z.; Khutoryanskiy, V.V.; Stewart, A.; Rahman, S.; Papahadjopoulos-Sternberg, B.; Dufes, C.; McCarthy, D.; Wilson, C.G.; Lyons, R.; Carter, K.C.; et al. Carbohydrate-based micelle clusters which enhance hydrophobic drug bioavailability by up to 1 order of magnitude. Biomacromolecules 2006, 7, 3452-3459. [CrossRef]

171. Tanner, T.; Marks, R. Delivering drugs by the transdermal route: Review and comment. Skin Res. Technol. 2008, 14, 249-260. [CrossRef]

172. Al-Kassas, R.; Wen, J.Y.; Cheng, A.E.M.; Kim, A.M.J.; Liu, S.S.M.; Yu, J. Transdermal delivery of propranolol hydrochloride through chitosan nanoparticles dispersed in mucoadhesive gel. Carbohydr. Polym. 2016, 153, 176-186. [CrossRef]

173. Hafner, A.; Lovric, J.; Pepic, I.; Filipovic-Grcic, J. Lecithin/chitosan nanoparticles for transdermal delivery of melatonin. J. Microencapsul. 2011, 28, 807-815. [CrossRef]

174. Shah, H.A.; Patel, R.P. Statistical modeling of zaltoprofen loaded biopolymeric nanoparticles: Characterization and antiinflammatory activity of nanoparticles loaded gel. Int. J. Pharm. Investig. 2015, 5, 20-27. [CrossRef]

175. Lopez-Leon, T.; Carvalho, E.L.; Seijo, B.; Ortega-Vinuesa, J.L.; Bastos-Gonzalez, D. Physicochemical characterization of chitosan nanoparticles: Electrokinetic and stability behavior. J. Colloid Interf. Sci. 2005, 283, 344-351. [CrossRef]

176. Fardet, L.; Flahault, A.; Kettaneh, A.; Tiev, K.P.; Genereau, T.; Toledano, C.; Lebbe, C.; Cabane, J. Corticosteroid-induced clinical adverse events: Frequency, risk factors and patient's opinion. Br. J. Dermatol. 2007, 157, 142-148. [CrossRef] [PubMed]

177. Ridolfi, D.M.; Marcato, P.D.; Justo, G.Z.; Cordi, L.; Machado, D.; Duran, N. Chitosan-solid lipid nanoparticles as carriers for topical delivery of tretinoin. Colloid Surf. B 2012, 93, 36-40. [CrossRef] [PubMed]

178. Dev, A.; Binulal, N.S.; Anitha, A.; Nair, S.V.; Furuike, T.; Tamura, H.; Jayakumar, R. Preparation of poly(lactic acid)/chitosan nanoparticles for anti-HIV drug delivery applications. Carbohyd. Polym. 2010, 80, 833-838. [CrossRef]

179. Dahmane, E.; Rhazi, M.; Taourirte, M. Chitosan Nanoparticles as a New Delivery System for the Anti-HIV Drug Zidovudine. Bull. Korean Chem. Soc. 2013, 34, 1333-1338. [CrossRef]

180. Tripathy, S.; Das, S.; Chakraborty, S.P.; Sahu, S.K.; Pramanik, P.; Roy, S. Synthesis, characterization of chitosan-tripolyphosphate conjugated chloroquine nanoparticle and its in vivo anti-malarial efficacy against rodent parasite: A dose and duration dependent approach. Int. J. Pharmaceut. 2012, 434, 292-305. [CrossRef] [PubMed] 
181. Nanda, R.K.; Patil, S.S.; Navathar, D.A. Chiotsan Nanoparticles Loaded with Thiocolchicoside. Der. Pharma. Chemica. 2012, 4, $1619-1625$.

182. Makhlof, A.; Tozuka, Y.; Takeuchi, H. Design and evaluation of novel pH-sensitive chitosan nanoparticles for oral insulin delivery. Eur. J. Pharm. Sci. 2011, 42, 445-451. [CrossRef]

183. Katas, H.; Alpar, H.O. Development and characterisation of chitosan nanoparticles for siRNA delivery. J. Control. Release 2006, 115, 216-225. [CrossRef]

184. Zhi, J.; Wang, Y.J.; Luo, G.S. Adsorption of diuretic furosemide onto chitosan nanoparticles prepared with a water-in-oil nanoemulsion system. React. Funct. Polym. 2005, 65, 249-257. [CrossRef]

185. Gan, Q.; Wang, T.; Cochrane, C.; McCarron, P. Modulation of surface charge, particle size and morphological properties of chitosan-TPP nanoparticles intended for gene delivery. Colloid Surf. B-Biointerfaces 2005, 44, 65-73. [CrossRef]

186. Cetin, M.; Aktas, Y.; Vural, I.; Capan, Y.; Dogan, L.A.; Duman, M.; Dalkara, T. Preparation and in vitro evaluation of bFGF-loaded chitosan nanoparticles. Drug Deliv. 2007, 14, 525-529. [CrossRef] [PubMed]

187. Bozkir, A.; Saka, O.M. Chitosan nanoparticles for plasmid DNA delivery: Effect of chitosan molecular structure on formulation and release characteristics. Drug Deliv. 2004, 11, 107-112. [CrossRef]

188. Xu, F.; Burg, K.J.L. Three-dimensional polymeric systems for cancer cell studies. Cytotechnology 2007, 54, 135-143. [CrossRef] [PubMed]

189. Fernandez-Urrusuno, R.; Calvo, P.; Remunan-Lopez, C.; Vila-Jato, J.L.; Alonso, M.J. Enhancement of nasal absorption of insulin using chitosan nanoparticles. Pharm. Res. 1999, 16, 1576-1581. [CrossRef]

190. Bellich, B.; D’Agostino, I.; Semeraro, S.; Gamini, A.; Cesaro, A. “The Good, the Bad and the Ugly" of Chitosans. Mar Drugs 2016, 14, 99. [CrossRef] [PubMed]

191. Das, R.K.; Kasoju, N.; Bora, U. Encapsulation of curcumin in alginate-chitosan-pluronic composite nanoparticles for delivery to cancer cells. Nanomedicine 2010, 6, 153-160. [CrossRef] [PubMed]

192. Zhao, Z.M.; He, M.; Yin, L.C.; Bao, J.M.; Shi, L.L.; Wang, B.Q.; Tang, C.; Yin, C.H. Biodegradable Nanoparticles Based on Linoleic Acid and Poly(beta-malic acid) Double Grafted Chitosan Derivatives as Carriers of Anticancer Drugs. Biomacromolecules 2009, 10, 565-572. [CrossRef]

193. Jeong, Y.I.; Jin, S.G.; Kim, I.Y.; Pei, J.; Wen, M.; Jung, T.Y.; Moon, K.S.; Jung, S. Doxorubicin-incorporated nanoparticles composed of poly(ethylene glycol)-grafted carboxymethyl chitosan and antitumor activity against glioma cells in vitro. Colloids Surf. B Biointerfaces 2010, 79, 149-155. [CrossRef]

194. Tian, Q.; Zhang, C.N.; Wang, X.H.; Wang, W.; Huang, W.; Cha, R.T.; Wang, C.H.; Yuan, Z.; Liu, M.; Wan, H.Y.; et al. Glycyrrhetinic acid-modified chitosan/poly(ethylene glycol) nanoparticles for liver-targeted delivery. Biomaterials 2010, 31, 4748-4756. [CrossRef] [PubMed]

195. Kim, J.H.; Kim, Y.S.; Kim, S.; Park, J.H.; Kim, K.; Choi, K.; Chung, H.; Jeong, S.Y.; Park, R.W.; Kim, I.S.; et al. Hydrophobically modified glycol chitosan nanoparticles as carriers for paclitaxel. J. Control. Release 2006, 111, 228-234. [CrossRef]

196. Trickler, W.J.; Khurana, J.; Nagvekar, A.A.; Dash, A.K. Chitosan and glyceryl monooleate nanostructures containing gemcitabine: Potential delivery system for pancreatic cancer treatment. Aaps. Pharmscitech. 2010, 11, 392-401. [CrossRef]

197. Zhou, Y.S.; Yang, D.Z.; Chen, X.M.; Xu, Q.; Lu, F.M.; Nie, J. Electrospun water-soluble carboxyethyl chitosan/poly(vinyl alcohol) nanofibrous membrane as potential wound dressing for skin regeneration. Biomacromolecules 2008, 9, 349-354. [CrossRef]

198. Zhou, Y.S.; Yang, H.J.; Liu, X.; Mao, J.; Gu, S.J.; Xu, W.L. Electrospinning of carboxyethyl chitosan/poly(vinyl alcohol)/silk fibroin nanoparticles for wound dressings. Int. J. Biol. Macromol. 2013, 53, 88-92. [CrossRef] [PubMed]

199. Fouda, M.M.; El-Aassar, M.R.; Al-Deyab, S.S. Antimicrobial activity of carboxymethyl chitosan/polyethylene oxide nanofibers embedded silver nanoparticles. Carbohydr. Polym. 2013, 92, 1012-1017. [CrossRef]

200. Kossovich, L.Y.; Salkovskiy, Y.; Kirillova, Y. Electrospun Chitosan Nanofiber Materials as Burn Dressing. In Proceedings of the 6th World Congress of Biomechanics, Singapore, 1-6 August 2010; pp. 1212-1214.

201. Zhao, Y.H.; Zhou, Y.; Wu, X.M.; Wang, L.; Xu, L.; Wei, S.C. A facile method for electrospinning of Ag nanoparticles/poly (vinyl alcohol)/carboxymethyl-chitosan nanofibers. Appl. Surf. Sci. 2012, 258, 8867-8873. [CrossRef]

202. Toshkova, R.; Manolova, N.; Gardeva, E.; Ignatova, M.; Yossifova, L.; Rashkov, I.; Alexandrov, M. Antitumor activity of quaternized chitosan-based electrospun implants against Graffi myeloid tumor. Int. J. Pharm. 2010, 400, 221-233. [CrossRef]

203. Alipour, S.M.; Nouri, M.; Mokhtari, J.; Bahrami, S.H. Electrospinning of poly(vinyl alcohol)-water-soluble quaternized chitosan derivative blend. Carbohydr. Res. 2009, 344, 2496-2501. [CrossRef] [PubMed]

204. Ignatova, M.; Starbova, K.; Markova, N.; Manolova, N.; Rashkov, I. Electrospun nano-fibre mats with antibacterial properties from quaternised chitosan and poly(vinyl alcohol). Carbohydr. Res. 2006, 341, 2098-2107. [CrossRef] [PubMed]

205. Ignatova, M.; Manolova, N.; Rashkov, I. Novel antibacterial fibers of quaternized chitosan and poly(vinyl pyrrolidone) prepared by electrospinning. Eur. Polym. J. 2007, 43, 1112-1122. [CrossRef]

206. Ignatova, M.G.; Manolova, N.E.; Toshkova, R.A.; Rashkov, I.B.; Gardeva, E.G.; Yossifova, L.S.; Alexandrov, M.T. Electrospun nanofibrous mats containing quaternized chitosan and polylactide with in vitro antitumor activity against HeLa cells. Biomacromolecules 2010, 11, 1633-1645. [CrossRef]

207. Ignatova, M.; Manolova, N.; Markova, N.; Rashkov, I. Electrospun non-woven nanofibrous hybrid mats based on chitosan and PLA for wound-dressing applications. Macromol. Biosci. 2009, 9, 102-111. [CrossRef] 
208. Bai, B.; Mi, X.; Xiang, X.; Heiden, P.A.; Heldt, C.L. Non-enveloped virus reduction with quaternized chitosan nanofibers containing graphene. Carbohydr. Res. 2013, 380, 137-142. [CrossRef] [PubMed]

209. Deng, H.B.; Lin, P.H.; Xin, S.J.; Huang, R.; Li, W.; Du, Y.M.; Zhou, X.; Yang, J.H. Quaternized chitosan-layered silicate intercalated composites based nanofibrous mats and their antibacterial activity. Carbohydr. Polym. 2012, 89, 307-313. [CrossRef]

210. Jiang, H.L.; Fang, D.F.; Hsiao, B.J.; Chu, B.J.; Chen, W.L. Preparation and characterization of ibuprofen-loaded poly(lactide-coglycolide)/poly(ethylene glycol)-g-chitosan electrospun membranes. J. Biomater. Sci.-Polym. Ed. 2004, 15, 279-296. [CrossRef]

211. Chen, H.L.; Huang, J.; Yu, J.H.; Liu, S.Y.; Gu, P. Electrospun chitosan-graft-poly (epsilon-caprolactone)/poly (epsilon-caprolactone) cationic nanofibrous mats as potential scaffolds for skin tissue engineering. Int. J. Biol. Macromol. 2011, 48, 13-19. [CrossRef] [PubMed]

212. Nawalakhe, R.G.; Hudson, S.M.; Seyam, A.F.M.; Waly, A.I.; Abou-Zeid, N.Y.; Ibrahim, H.M. Development of Electrospun Iminochitosan for Improved Wound Healing Application. J. Eng. Fiber Fabr. 2012, 7, 47-55. [CrossRef]

213. Seyam, A.F.M.; Hudson, S.M.; Ibrahim, H.M.; Waly, A.I.; Abou-Zeid, N.Y. Healing performance of wound dressing from cyanoethyl chitosan electrospun fibres. Indian J. Fibre Text. 2012, 37, 205-210.

214. Datta, P.; Dhara, S.; Chatterjee, J. Hydrogels and electrospun nanofibrous scaffolds of N-methylene phosphonic chitosan as bioinspired osteoconductive materials for bone grafting. Carbohydr. Polym. 2012, 87, 1354-1362. [CrossRef]

215. Deng, H.; Lin, P.; Li, W.; Xin, S.; Zhou, X.; Yang, J. Hydroxypropyl chitosan/organic rectorite-based nanofibrous mats with intercalated structure for bacterial inhibition. J. Biomater. Sci. Polym. Ed. 2013, 24, 485-496. [CrossRef]

216. Venkatesan, P.; Puvvada, N.; Dash, R.; Prashanth Kumar, B.N.; Sarkar, D.; Azab, B.; Pathak, A.; Kundu, S.C.; Fisher, P.B.; Mandal, $\mathrm{M}$. The potential of celecoxib-loaded hydroxyapatite-chitosan nanocomposite for the treatment of colon cancer. Biomaterials 2011, 32, 3794-3806. [CrossRef] [PubMed]

217. Qian, L.L.; Zheng, J.J.; Wang, K.; Tang, Y.; Zhang, X.F.; Zhang, H.S.; Huang, F.P.; Pei, Y.Y.; Jiang, Y.Y. Cationic core-shell nanoparticles with carmustine contained within O-6-benzylguanine shell for glioma therapy. Biomaterials 2013, 34, 8968-8978. [CrossRef]

218. Deng, X.; Cao, M.; Zhang, J.; Hu, K.; Yin, Z.; Zhou, Z.; Xiao, X.; Yang, Y.; Sheng, W.; Wu, Y.; et al. Hyaluronic acid-chitosan nanoparticles for co-delivery of MiR-34a and doxorubicin in therapy against triple negative breast cancer. Biomaterials 2014, 35, 4333-4344. [CrossRef]

219. Hu, Y.W.; Du, Y.Z.; Liu, N.; Liu, X.; Meng, T.T.; Cheng, B.L.; He, J.B.; You, J.; Yuan, H.; Hu, F.Q. Selective redox-responsive drug release in tumor cells mediated by chitosan based glycolipid-like nanocarrier. J. Control. Release 2015, 206, 91-100. [CrossRef]

220. Tekade, R.K.; Youngren-Ortiz, S.R.; Yang, H.N.; Haware, R.; Chougule, M.B. Albumin-chitosan hybrid onconase nanocarriers for mesothelioma therapy. Cancer Res. 2015, 75. [CrossRef]

221. Butt, A.M.; Amin, M.C.; Katas, H.; Abdul Murad, N.A.; Jamal, R.; Kesharwani, P. Doxorubicin and siRNA Codelivery via Chitosan-Coated pH-Responsive Mixed Micellar Polyplexes for Enhanced Cancer Therapy in Multidrug-Resistant Tumors. Mol. Pharm. 2016, 13, 4179-4190. [CrossRef]

222. Lin, J.T.; Liu, Z.K.; Zhu, Q.L.; Rong, X.H.; Liang, C.L.; Wang, J.; Ma, D.; Sun, J.; Wang, G.H. Redox-responsive nanocarriers for drug and gene co-delivery based on chitosan derivatives modified mesoporous silica nanoparticles. Colloids Surf. B Biointerfaces 2017, 155, 41-50. [CrossRef]

223. Zhang, J.; Wang, Y.; Jiang, Y.; Liu, T.; Luo, Y.; Diao, E.; Cao, Y.; Chen, L.; Zhang, L.; Gu, Q.; et al. Enhanced cytotoxic and apoptotic potential in hepatic carcinoma cells of chitosan nanoparticles loaded with ginsenoside compound K. Carbohydr. Polym. 2018, 198, 537-545. [CrossRef] [PubMed]

224. Muddineti, O.S.; Shah, A.; Rompicharla, S.V.K.; Ghosh, B.; Biswas, S. Cholesterol-grafted chitosan micelles as a nanocarrier system for drug-siRNA co-delivery to the lung cancer cells. Int. J. Biol. Macromol. 2018, 118, 857-863. [CrossRef] [PubMed]

225. Guo, X.; Zhuang, Q.; Ji, T.; Zhang, Y.; Li, C.; Wang, Y.; Li, H.; Jia, H.; Liu, Y.; Du, L. Multi-functionalized chitosan nanoparticles for enhanced chemotherapy in lung cancer. Carbohydr. Polym. 2018, 195, 311-320. [CrossRef] [PubMed]

226. Lee, D.E.; Koo, H.; Sun, I.C.; Ryu, J.H.; Kim, K.; Kwon, I.C. Multifunctional nanoparticles for multimodal imaging and theragnosis. Chem. Soc. Rev. 2012, 41, 2656-2672. [CrossRef]

227. Stigliano, C.; Aryal, S.; De Tullio, M.D.; Nicchia, G.P.; Pascazio, G.; Svelto, M.; Decuzzi, P. siRNA-Chitosan Complexes in Poly(lactic-co-glycolic acid) Nanoparticles for the Silencing of Aquaporin-1 in Cancer Cells. Mol. Pharmaceut. 2013, 10, 3186-3194. [CrossRef] [PubMed]

228. Saboktakin, M.R.; Tabatabaie, R.M.; Maharramov, A.; Ramazanov, M.A. Synthesis and in vitro studies of biodegradable modified chitosan nanoparticles for photodynamic treatment of cancer. Int. J. Biol. Macromol. 2011, 49, 1059-1065. [CrossRef] [PubMed] 